\title{
The Subversion of Shareholder Democracy and the Rise of Hedge-Fund Activism ${ }^{1}$
}

\author{
Jang-Sup Shin ${ }^{2}$
}

\section{Working Paper No. 77}

\author{
July 2018
}

\begin{abstract}
This paper explains how hedge-fund activists are exerting power over corporate resource allocation far in excess of the actual voting power of their shareholdings. The power of these "minority-shareholding corporate raiders" derives from misguided regulatory "reforms" carried out in the 1980s and 1990s in the name of "shareholder democracy". Sanctioned and overseen by the Department of Labor (DOL) and the Securities and Exchange Commission (SEC), these reforms include the introduction of compulsory voting by institutional investors and proxyvoting rule changes that greatly facilitated hedge-fund activists' aggregation of the proxy votes
\end{abstract}

\footnotetext{
${ }^{1}$ This paper is drawn from my collaborative research with William Lazonick on hedge-fund activism, corporation and economy that resulted in a book manuscript, Value Creation and Value Extraction: The Manifesto to Reclaim Sustainable Prosperity. I thank Bill for his continued encouragement and intellectual companionship. I also thank Matt Hopkins for his inputs on hedge funds. Funding for this research came from the Institute for New Economic Thinking under Grant IN017-00013: "Value Creation and Methods of Value Extraction in US Firms".

${ }^{2}$ National University of Singapore 
of institutional investors. In addition, the introduction of the 1996 National Securities Markets Improvement Act (NSMIA) that allowed hedge funds to draw funds from institutional investors effectively with no limit also played an important role in the rise of hedge-fund activism. The paper concludes with policy proposals to rebalance value creation and value extraction by rebuilding the engagement and proxy voting system including (1) making it mandatory for shareholders to submit justifications in shareholder proposals on value creation or capital formation of corporations concerned; (2) removing voting as a fiduciary duty of institutional investors; (3) introducing differentiated voting rights that favor long-term shareholders; and (4) making it mandatory for both shareholders and management to reveal to the public what they discussed in engagement sessions.

JEL Codes: G18, G28, K22, L21, M10, N22

Keywords: Shareholder democracy, Hedge-fund activism, Compulsory voting of institutional investors, Engagement and proxy rules, Proxy advisory firms, New Deal financial regulations, Sustainable value creation and value extraction. 


\section{Introduction}

The value extracting power of hedge-fund activists is hardly comprehensible to casual observers. They are mere "minority shareholders". Yet they exert enormous influence over the governance of corporations, often forcing them to undertake fundamental restructuring and to increase stock buybacks and dividends substantially. For instance, Third Point Management and Trian Fund Management, holding only $2 \%$ of outstanding stock of Dow Chemical and Du Pont respectively, engineered a merger-and-split of America's top two chemical giants at the end of 2015, resulting in massive layoffs and closure of DuPont's central research lab, the first industrial science lab in the United States. ${ }^{3}$ Carl Icahn, after acquiring about $1 \%$ of Apple's stock in 2013, pressed the most valuable company in the world at the time to repurchase a recordbreaking $\$ 80$ billion of its outstanding stock in 2014-2015, and took $\$ 2$ billion of profit for himself when he quietly sold his entire stake in $2016 .^{4}$

Elliot Management, whose efforts to enforce full payment of bonds issued by poor countries in Africa and Latin America through litigation and other measures had already attracted wide attention, purchased about $0.5 \%$ of outstanding stock of Samsung Electronics in early fiscal 2016. It then demanded that the largest electronics company in the world by revenue split itself into a holding company and an operating company while radically increasing "shareholder-friendly" measures by paying out special dividends of about \$26 billion (KRW30 trillion). This hedge-fund attack led the company to embark on about \$8 billion (KRW9.4 trillion) of additional stock buybacks on top of about $\$ 9.9$ billion (KRW11.3 trillion) of stock buybacks it had been doing over the previous year, apparently as "compensation" for its rejection of

\footnotetext{
${ }^{3}$ Gandel (2015); 'Dissecting the Dow And DuPont Deal, From Merger To Split?' Forbes, August 30, 2016 (https://www.forbes.com/sites/greatspeculations/2016/08/30/dissecting-dow-and-dupont-deal-from-merger-tosplit/\#1414e3286967); 'DowDupont Names Its Three New Separate Businesses', Chemistry World, March 1, 2018 (https://www.chemistryworld.com/news/dowdupont-names-its-three-new-separate-businesses/3008721.article). 4 Lazonick, Hopkins and Jacobson (2016); 'Billionaire Icahn Exits Apple Stake After Three Years', Bloomberg, April 29, 2016 (https://www.bloomberg.com/news/articles/2016-04-28/billionaire-icahn-exits-apple-stake-almost-3years-after-buying).
} 
Elliott's demand to split the company and pay a special dividend. ${ }^{5}$ It is now increasingly difficult to find incidents in which management goes against hedge-fund activists' proposals outright and risk proceeding to a proxy voting showdown in shareholder meetings. As Steven Solomon commented, "companies, frankly, are scared" and "[their] mantra ... is to settle with hedge funds before it gets to a fight over the control of a company." ${ }^{6}$

This paper explains why and how hedge-fund activists have acquired power disproportionate to their actual shareholding and discusses the implications of this power for government policy and corporate management. Hedge-fund activists are descendants of the corporate raiders whose junk-bond-fueled attacks on US businesses in the 1980s were at the center of what became known as the "deal decade." With the collapse of the junk bond market in the late 1980s, corporate raiders reinvented themselves as "hedge-fund activists." ${ }^{7}$ Both corporate raiders and hedge-fund activists exploit their positions as shareholders to extract value from companies. They are only different in that the former did so by becoming (or threatening to become) majority shareholders whereas the latter do so as while remaining minority shareholders.

This paper argues that the power of these "minority-shareholding corporate raiders" derives from misguided regulatory "reforms" carried out in the 1980s and 1990s in the name of "shareholder democracy." Sanctioned and overseen by the Department of Labor (DOL) and the Securities and Exchange Commission (SEC), these reforms include the introduction of compulsory voting by institutional investors and proxy-voting rule changes that greatly facilitated hedge-fund activists' aggregation of the proxy votes of institutional investors. In addition, the introduction of the 1996 National Securities Markets Improvement Act (NSMIA)

\footnotetext{
5 'Samsung in Cross Hairs of American Hedge Fund', New York Times, Oct. 5, 2016 (http://nyti.ms/2dxarlk); 'The Current State and Direction of Samsung Electronics' Stock Buybacks' (in Korean), Mirae Asset Daily Report, Sept. 15, 2017.

${ }^{6}$ Solomon (2015).

${ }^{7}$ Corporate raiders in fact bifurcated into hedge-fund activists and private-equity funds. In the latter, traditional methods of corporate raiding by becoming majority shareholders continued to be practiced although the conventional term, "hostile takeover," gave way to simple "takeover" as hostile takeover activities were established as a norm in the corporate and financial world. In this paper, I am only focusing on transformation of corporate raiders into hedge-fund activists.
} 
allowed hedge funds to draw unlimited funds from institutional investors to conduct their attacks on target corporations.

Underpinning these regulatory changes was the rapid growth of institutional shareholding, with some pension funds engaging in their own brand of shareholder activism. In historical perspective, institutional activism is a recent phenomenon. The New Deal financial regulations of the 1930s enforced passivity on institutional investors in their relations with corporate management. The norm of institutional-investor passivity only began changing from the middle of the 1980s. To make sense of the recent transformation of the relation between business corporations and institutional investors, it is necessary to understand why institutional investors were originally under heavy regulation.

\section{The movement for shareholder democracy and New Deal financial regulation}

When the U.S. public stock market was taking shape in the early $20^{\text {th }}$ century, those who came to own public shares were mostly retail investors - that is, individual households. Each holding a miniscule percentage of a corporation's shares outstanding, they had no ability or incentive to engage with corporate management. Their general willingness to leave control to managers stemmed in part from the prior revenue-generating successes of those corporations under managerial control and in part from the trust the shareholders had in financial intermediaries who had persuaded them to buy corporate stock. But, more fundamentally, this willingness to abdicate control derived from the confidence of public shareholders that the shares they held were liquid and that they could therefore sell them on the stock market at any time, a maneuver that became known as "the Wall Street Walk." Another reason they were willing to hold public stocks was that their ownership stake in a company entailed commitment of neither their time or effort, while their liability was limited only to the cash that they had paid for those shares. They would not have bought the shares in the first place had they been obliged to provide such commitment or to assume the corporation's financial liabilities. ${ }^{8}$

\footnotetext{
${ }^{8}$ Lazonick and O'Sullivan (2000); Lazonick (2014).
} 
Those who from the early $20^{\text {th }}$ century had embraced and promoted "investor democracy," or "shareholder democracy," were not at all interested in encouraging these public shareholders to influence management decisions, the hallmark of current-day shareholder activism. As Julia Ott has argued in When Wall Street Met Main Street: The Quest for Investors' Democracy, the main concern of "intellectual, political, corporate, and financial leaders who embarked on a quest for mass investment" was how to build a stable and prosperous political system in the face of not only public distrust of "corporate power and accountability" but also of political challenges of internal integration from "mounting economic inequality, surging immigration, ethnic diversity, Jim Crow segregation, and women's demands for suffrage [that] sparked fundamental debates about citizenship." They hoped that "[m]ass investment could shore up the propertied foundations of citizenship, preserve economic mobility and autonomy, enhance national prosperity, and make corporations accord with the will of the people." ${ }^{9}$ At its inception, shareholder democracy was premised on retail shareholders who had political citizenship in the country. Institutional investors such as investment trusts and mutual funds were only beginning to emerge. They were simply "money managers", who were not seen as having any part in shareholder democracy because they were fiduciaries, not owners, and did not have the status of citizens. ${ }^{10}$

Traditional regulations on institutional investors emerged in the New Deal era as a policy response to the turmoil of the New York Stock Exchange crash of 1929 and the subsequent collapse of economic activity. The Securities Act of 1933 and the Securities Exchange Act of 1934, the second of which established the Securities and Exchange Commission (SEC), sought to regulate financial markets. The specific regulation of mutual funds had to await passage of the

\footnotetext{
${ }^{9}$ Ott (2011: 4). For instance, Clark (1900) envisioned that the share ownership by workers would "blur, or perhaps disappear ... the old line of demarcation between the capitalist class and the laboring class" and argued "The socialist is not the only man who can have beatific visions" (Quoted in Ott (2011: 25)). This vision has continued into the 1920s and John Raskob, for instance, made his famous statement in 1929, "Everyone ought to be rich", by laying out proposals for working- and middle-class wealth building in an article in Ladies Home Journal (John J. Raskob papers (Accession 0473), Hagley Museum and Library, Wilmington, DE 19807, https://findingaids.hagley.org/xtf/view?docld=ead/0473.xml).

${ }^{10}$ The promoters of shareholder democracy of a century ago also made it clear that they did not think of it as having relation to raising capital. So Ott (2011: 4) states that they "did not view mass investment as a particularly efficient or profitable means of raising capital" and points out "[c]orporate need for capital did not call forth popular demand for financial securities spontaneously".
} 
Investment Company Act of 1940. The New Deal financial regulations embodied three enduring principles to guide the relation between shareholders and companies: (1) that "fraud and deceit", including profiting from insider information, be prohibited; (2) that investors acting as a group be heavily regulated and the forming of investors' cartels prohibited; and (3) that investors be encouraged to diversify their portfolios and discouraged from exerting influence over management.

Under the first principle, the regulations required public companies to make regular, accurate, and timely public disclosure of financial information to shareholders while barring shareholders and managers from profiting from insider information and misappropriating corporate resources. They specifically prohibited "fraud or deceit" and "manipulative or deceptive devices or contrivances." ${ }^{11}$ To deter insider trading, they required those who were deemed insiders, whether manager-owners or investors, to "report all purchases and sales of company securities". In addition, they stipulated that, should insiders "profit by buying a company's securities and selling them within six months or by selling and rebuying within six months, they may be required to forfeit those profits to the company."12

Under the second principle, the formation of a "voting group" by investors was considered to represent an investor cartel, a practice that was heavily regulated. If the combined shares of a group of investors exceeded a specified threshold, its members were placed under the same regulations as insiders. In view of the fact that investors intending to form a group would need to communicate with one another in advance, communication among investors came in for strict oversight: The Securities Exchange Act of 1934 ruled that "If one institution contacted enough others, the communications would be deemed a proxy solicitation. ... Filing would have to be made; the filers would have to give those contacted the information specified in Schedule 14A. Similarly, the securities acts trigger liability of controlling persons for illegal actions by the controlled company. Groups that control could be liable for the misdeeds of the controlled portfolio company." ${ }^{13}$

\footnotetext{
${ }^{11}$ Blair (1995: 51)

${ }^{12}$ Blair (1995: 51)

${ }^{13}$ Roe (1990: 17). Blair (1995: 71) points out that this regulation made it "difficult for shareholders to communicate with each other at all ... without the approval and support of management."
} 
In line with the third principle, institutional investors were encouraged to diversify their portfolios while being discouraged from seeking to control management. The 1934 Pecora Report, the product of a Senate securities investigation, explicitly walled institutional investors off from management, making clear that mutual funds were allowed to engage in investment only. ${ }^{14}$ This principle was also embodied in the Tax Code of 1936: "another safeguard ... is to prevent an investment trust or investment corporation [from] being set up to obtain control of some corporation and to manipulate its affairs." ${ }^{15}$ In enacting the Investment Company Act of 1940, a high-ranking SEC official even testified that "a mutual fund's only positive function was to provide diversification; any extension risked thievery." ${ }^{16}$

This regulation that clearly separated management from institutional investors answered in part to the need to remove the potential for conflict of interest: If institutional investors were allowed to control corporations, they would tend to utilize their position for their own profit at the expense of other shareholders. More important, behind the regulation was a clear understanding that institutional investors and management perform fundamentally different functions: While the former is basically speculators and/or savers who help individuals invest in corporate stock through utilizing their size and diversification, the latter creates value in corporations by producing low-cost and/or high-quality products and services. ${ }^{17}$ The mutual fund industry then did not oppose the regulations imposed by the government and, on the contrary, the industry readily accepted the regulations because it "wanted to sell its products and needed a code of conduct to certify the industry to the public."18

These three principles had been well enough established that they went unchallenged until the 1980s. For instance, the same principles were upheld when the Employee Retirement Income Security Act (ERISA) was introduced in 1974 as a policy response to the growing need to regulate pensions. First, ERISA rules prevented self-dealing behavior on the part of employers and fund managers. Second, they discouraged pension funds from taking excessive risks and

\footnotetext{
${ }^{14}$ Roe (1990: 12). For details on the Pecora Report, refer to Perino (2010); U.S. Senate Committee on Banking and Currency (2009).

${ }^{15}$ Roe (1991: 1483).

${ }^{16}$ Roe (1991: 1488). The emphasis is original.

${ }^{17}$ For details on this, refer to Lazonick (2015) and Lazonick and Shin (2018 forthcoming, Chapter 2).

${ }^{18}$ Roe (1991: 1489).
} 
encouraged them to diversify investment portfolios very broadly. Third, pension funds were requested to refrain from exercising control over companies in their portfolio; if they tried to do so, they could lose their tax-exempt status. ${ }^{19}$ In this context, Peter Drucker pointed out that pension funds "have no business trying to 'manage' ... To sit on a board of directors, for instance, and accept the obligations of board membership, is incompatible with duties as 'trustees' ... which have been sharply and strictly defined in the Pension Fund Reform Act of 1974 [ERISA]."20

\section{The progression of institutional activism}

Beginning in the 1980s, however, these principles came increasingly under assault. As will be elaborated below, shareholder activists advanced the new credos of "corporate citizenship" and "relational investing," and regulatory authorities, such as the SEC, the Department of Labor and Department of Treasury, started to side with the activists. Underlying the transformation was the rapidly growing power of institutional investors in corporate shareholding on which shareholder activists found ways to leverage. ${ }^{21}$ As shown in Figure 1, institutional shareholding of U.S. public stocks was at only $9 \%$ in 1950 , but increased to $14 \%$ in $1960,22 \%$ in $1970,32 \%$ in $1980,45 \%$ in $1990,55 \%$ in 2000 , and $63 \%$ in 2015 . If one includes hedge funds and privateequity funds in institutional investors, the actual institutional shareholding would be substantially higher than Figure 1 shows. ${ }^{22}$

\footnotetext{
${ }^{19}$ Blair (1995: 157).

${ }^{20}$ Drucker (1976: 83).

${ }^{21}$ The transformation was also legitimized by the broad acceptance of agency theory, which underpinned the ideology that a company should be run to maximize shareholder value.

${ }^{22}$ In Figure 1, drawn from the Federal Reserve data set, hedge funds and private-equity funds are classified as "households", not as "institutional investors", despite the fact that most of them are functioning as institutions by pooling and managing other people's money. This conventional definition of institutional investor also arose from loopholes in financial regulations (Dayen 2016).
} 
Figure 1. The Growth of Institutional Shareholding in the United States

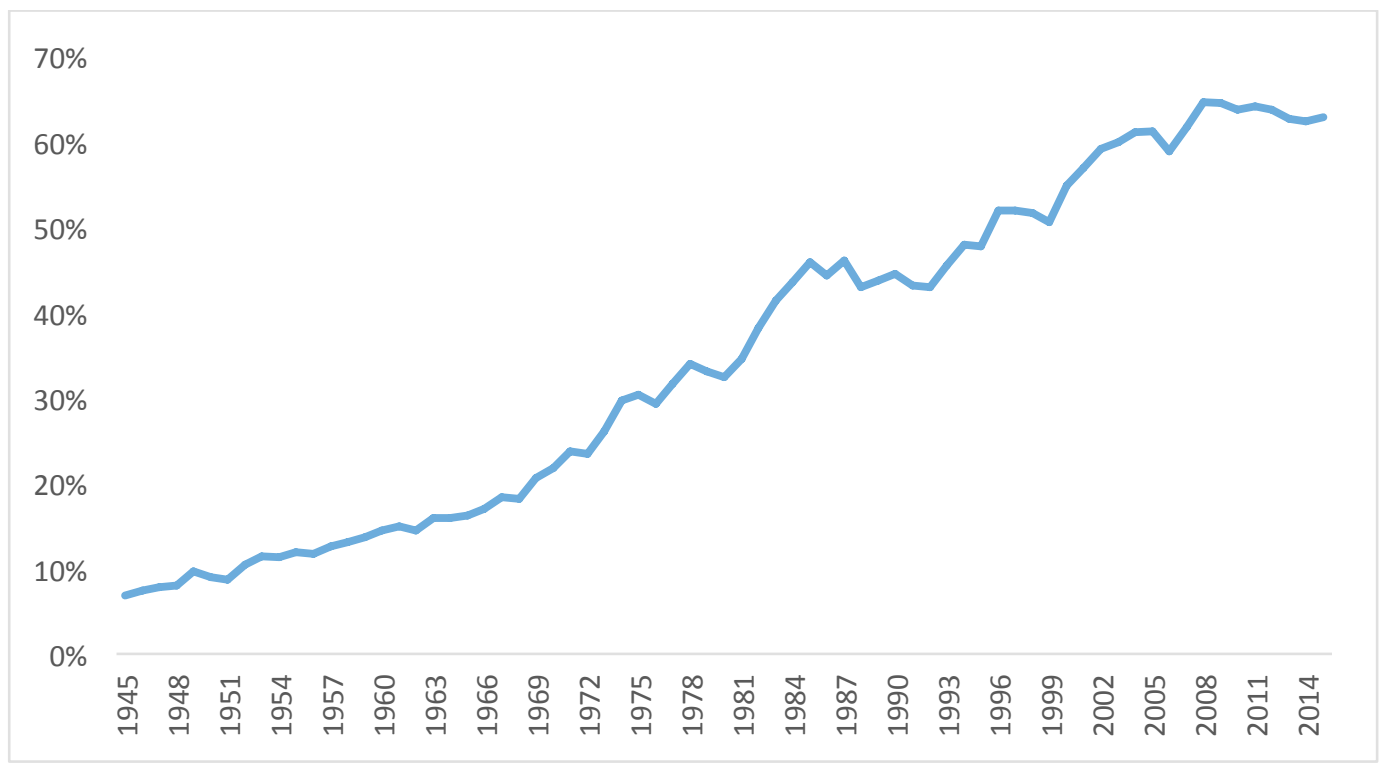

Source: Federal Reserve Board

There were various groups of activists who, in the 1980s, pursued corporate reforms to obtain what they considered public benefits. At the same time, there were groups of investors, including corporate raiders, who did not hide their determination to profit from the process of "reforming" corporations. In the name of "shareholder democracy," this coalition of reformers and raiders succeeded in bringing about major changes in the traditional New Deal financial regulations. ${ }^{23}$ The upshot of the regulatory changes is presented in Figure 2.

\footnotetext{
${ }^{23}$ On the evolution of corporate governance discourse, refer to Cheffins (2013).
} 
Figure 2. Changes in regulations on the relation between institutional investors and corporations

The New Deal financial regulations in the 1930s

- Established the principle of separation between public shareholding and corporate management

\section{ERISA regulation in 1974}

- Maintained the New Deal principles

Avon letter and DOL-DOF directives in 1988-9

- Compulsory voting for pension funds

SEC proxy rule change in 1992

- Allowing de facto investor cartels

- Unlimited freedom of "communication and engagement"

SEC final rule on proxy voting in 2003

- Compulsory voting for mutual funds and other investment advisers 


\subsection{Robert Monks and ISS: Compulsory voting of Institutional Investors}

Robert Monks, later described as "an entrepreneur of the idea of corporate governance" or "an agent of change in corporate governance," ${ }^{24}$ was the principal ideologue and administrator to provide justification for institutional activism as well as a businessman to profit from establishing Institutional Shareholder Service (ISS), the most prominent proxy voting firm, by almost single-handedly making proxy voting a fiduciary duty of institutional investors. A close consideration of his arguments and his career illuminates the evolution and consequences of institutional activism.

Monks joined the Department of Labor as Administrator of the Office of Pension and Welfare Benefit Programs in 1984, after previously working as a lawyer, businessman, and banker, and having been an aspiring politician. "The only reason Monks took this job was to advance his governance agenda," according to Hilary Rosenberg, his biographer. "His main concern [was] establishing the position that pension funds had fiduciary duties to act as owners of corporations." ${ }^{25}$ From the beginning of his tenure, he intended to serve only one year as a pension administrator and to leverage his experience in government for a business career in corporate governance. $^{26}$

In a speech, "The Institutional Shareholder as a Corporate Citizen", later considered seminal among corporate-governance activists, Monks told pension plan officers that

"it seems to me to be a self-evident proposition, that institutional investors have to be activist corporate citizens....Given the huge blocks of stocks owned by institutions in all of our major companies, it is not always practical to quietly support management or...sell if you don't approve of management's handling of the company. I would suggest that it

\footnotetext{
${ }^{24}$ Rosenberg (1999).

${ }^{25}$ Rosenberg (1999: 83-84).

${ }^{26}$ Rosenberg (1999: 80), borrowing Monks's own words, details this decision as follows: “On the taking the pension job, Monks vowed - to himself and his family - that he would stay in the position for just one year. ... he told his wife ... 'Trust me', he remembers saying to her ... 'I know my own temperament in the government. I have a single agenda for this. I'm not going into this because I want to be a career public servant. I'm going into this because it's in aid of my long-term project in trying to create change in the way that corporations function. I can't afford more than a year's time here.'”
} 
behooves institutional investors, in the exercise of their corporate citizenship, to take the lead in proposing, and passing, provisions...Even if you wanted to run away from a poorly managed company, you couldn't do it at once...So like it or not,...as a practical business matter, institutional investors are going to have to become more and more active shareholder-owners, and less and less passive investors, ..."27

Two aspects of this speech demand our attention: the call for stronger activism and the use of the term "owners." As to the first point, Monks took for granted, as did later corporategovernance activists, that with the growth of institutional shareholding, it had become more difficult for investors to resort to the "Wall Street walk." The advocacy of stronger institutional activism was a corollary of this growing difficulty. From the perspective of the traditional regulations on institutional investors that encouraged diversification, however, this argument puts the cart before the horse. Diversification was encouraged not only to spread out risks across a portfolio of assets but also to make it easier for institutional investors to take the Wall Street walk by selling off blocks of shares in a portfolio when the need would arise. As institutional shareholding grew, the market for selling blocks of shares became more liquid, actually making it easier for an institutional investor to take the Wall Street walk by selling its shares to other institutional investors. Given the liquid stock market, there are no grounds for saying that any particular institutional investor is "stuck" with certain portfolios. But Monks employed the growth of institutional shareholding in aggregate as a pretext for claiming that their shareholdings are illiquid and therefore stronger institutional activism was needed.

A crucial tactic in advancing this argument for stronger activism is to portray institutional investors as if they are homogeneous. They are, however, a diverse group that includes pension funds, mutual funds, sovereign wealth funds, university endowments, insurance companies,

\footnotetext{
${ }^{27}$ Rosenberg (1999: 92-93). Rosenberg (1999: 101) also quotes his similar speech at the Financial Analysts Foundation (FAF) as follows: "Like it or not, pension funds were permanent investors in corporate America and becoming more so by the day. Increasingly, they were the deciding factor in ongoing battle for corporate control."
} 
bank trusts, and other investment companies. ${ }^{28}$ Institutional investors are in general competing fiercely with each other to improve investment performance and attract more customers. Treating them as a group and urging them to strengthen their activism in regard to companies bordered on requesting them to form investor cartels.

As to the second point, it is an intentional misrepresentation to say that large blocks of stock are "owned" by institutions. Institutional investors are fiduciaries or trustees of those households or organizations whose money they are managing. As a law student, Monks himself was clearly aware of this legal situation and used the term "fiduciaries" not infrequently in his writings and speeches. At the same time, however, he often used the term "owners." This rhetorical tactic to portray institutional investors as "owners" has successfully contributed to the broad acceptance of a vertical relation of "owner versus manager"; that is, that corporate managers are agents of institutional investors who "own" the companies. ${ }^{29}$ In fact, corporate managers are business-managing fiduciaries as much as institutional investors are moneymanaging fiduciaries, and their relation is a horizontal one between two different fiduciaries. Monks, as well as other shareholder activists, nonetheless distorted this relation in public discourse and increasingly in minds of policy-makers, academics, and even businesspeople.

Another significant contribution of Monks to institutional activism and later to hedge-fund activism was his establishment of the proxy advisory firm ISS. He set up the company immediately after resigning from the Department of Labor in $1985 .^{30}$ He had already proposed the idea of ISS while he was the chief pension administrator, arguing in a December 1984 speech: "Current fiduciaries have neither the inclination nor the training to act as proprietors. Either they have to acquire them [capabilities to vote], or a new institution will be developed." 31 He later provided more details regarding this "new institution" at a Labor

\footnotetext{
${ }^{28}$ Even among pension funds, over which Monks had influence as the chief U.S. government pension administrator in 1984-1985, the investment objectives and approaches of private pension funds differ from one to another as well as from those of public pension funds.

${ }^{29}$ This tactic was supported by the concurrent rise of agency theories and the maximizing shareholder value (MSV) view in the 1980s.

${ }^{30}$ Initially, its name was Institutional Investors Service and Monks changed the name to Institutional Shareholder Services in the same year.

${ }^{31}$ Rosenberg (1999: 102).
} 
Department hearings, saying "[i]t was time ... for corporate, ERISA-covered pension fund sponsors and their managers to assign the vote to a third, neutral party." ${ }^{32}$

Monks was not only a shareholder activist in his presumed public interest, but also a businessman who wanted to profit by "selling the idea of a company that carried out voting tasks for funds." He had made it clear from the beginning - to his family, at least - that he would stay with DOL for only a year, and then pursue his corporate-governance agenda in the business sector. One fund manager directly admonished Monks for his conflicting interests in his campaign for a "third, neutral party" to advise proxy voting: "Monks, goddamn you. Guys like you, you go into government and start a forest fire and then you come and try to sell us all fire extinguishers." 33

This "double helix" activism of Monks was realized by regulatory changes that progressively define voting as a fiduciary duty of institutional investors. ${ }^{34}$ The first of the changes, carried out by his colleagues remaining at DOL, was the so-called "Avon letter" in 1988 that clarified the Department's position on the fiduciary duty of pension funds under ERISA. ${ }^{35}$ This position was reiterated in "Statements on Pension Funds Investment" issued by the Department of Labor and the Department of the Treasury in $1989 .{ }^{36}$ Through these administrative directives, proxy voting was established as a fiduciary duty of pension fund managers, and they were required to vote in what they regarded as the "economic best interest of a plan's participants and

\footnotetext{
${ }^{32}$ Rosenberg (1999: 103).

${ }^{33}$ Rosenberg (1999: 117) continued to say, "Monks was astonished. Here was someone who saw right through him. He was indeed interested in selling the idea of a company that carried out voting tasks for funds."

${ }^{34}$ Monks himself employed this analogy of double helix to justify his personal profit-seeking as compatible with the public benefit of shareholder activism. Pointing to the structure of DNA, which consists of two strands of molecules arrayed as a twisted ladder, he argued that one strand represented the "mission" of activism, the other strand "money" to be earned from activism. Monks said he wanted to "pursue the development of corporate governance through the structure of a profit-making business," explaining: "As a business, my idea had to be made relevant to people who were accustomed to paying only for something that was in fact valuable to them. I had to demonstrate that year in and year out good governance was good business. ... The parallel spiral forces of the double helix do not touch but are indispensable to each other." (Refer to Rosenberg 1999: 118).

${ }^{35}$ The letter sent by a deputy assistant secretary at DOL to the Retirement Board of Avon Products Inc. stated as follows: "The decision as to how proxies should be voted with regard to the issues presented by the fact pattern are fiduciary acts of plan asset managers." In a subsequent speech, the then-assistant secretary of DOL asserted that "to meet this obligation, pension plan sponsors under ERISA must draw up detailed policies governing proxy voting and document all votes and the reasons behind them." (Rosenberg 1999: 165)

${ }^{36}$ The Avon letter has thus been "widely cited as the Labor Department's official position on fiduciary obligations of pension fund managers to vote the shares under their management." (Blair 1995: 158)
} 
beneficiaries." ${ }^{37}$ ISS was losing money since its inception because pension funds were not interested in hiring ISS's service. Not of their own accord but under the new regulation, however, pension funds now faced the necessity of seeking professional advice from the "third, neutral party." The business of ISS then took off.

This fiduciary duty of voting imposed on pension funds was extended later to all other institutional investors, including mutual funds, under an SEC regulation. In its ruling on proxy voting in 2003 , the SEC made clear that "... an adviser is a fiduciary that owes each of its clients duties of care and loyalty ..., including proxy voting" and required advisers "to adopt and implement policies and procedures for voting proxies in the best interest of clients, to describe the procedures to clients, and to tell clients how they may obtain information about how the adviser has actually voted their proxies." ${ }^{38}$ Until the SEC rule in 2003, ISS was a monopoly proxy advisor. Glass Lewis, now the second largest proxy advisory firm, entered the proxy advisory market in the same year.

Through his initiative to make institutional investors "active corporate citizens", Monks' business ambitions were largely fulfilled. After being investigated by the SEC for potential conflict of interest, he left ISS on paper in 1990, transferring \$3 million worth of his shares in the company to an irrevocable trust and making his nephew Nicholas Higgins and his son Robert the trustees. ${ }^{39}$ He then continued his corporate-governance activism in the "doublehelix" fashion by setting up "corporate-governance funds" like the Lens Fund. ${ }^{40}$ ISS successfully grew into a global company that currently maintains "approximately 900 employees spread across 17 offices in 12 countries, covering approximately 39,000 meetings in 115 countries yearly, delivering proxy research and vote recommendations .... [for] more than 8.5 million ballots representing two trillion shares." ${ }^{41}$ However, it is extremely questionable whether Monks' attempt to serve the public interest has been fulfilled, as will be discussed in Section 4.

\footnotetext{
${ }^{37}$ Blair (1995: 158).

${ }^{38}$ SEC (2003).

${ }^{39}$ Rosenberg (1999: 211-14).

${ }^{40}$ Corporate governance funds aims at increasing investment yields by applying pressure to improve corporate governance of their portfolio companies.

${ }^{41}$ ISS website, https://www.issgovernance.com/about/about-iss/. Accessed on April 10, 2016.
} 


\subsection{Shareholder activists acting together: Public pension funds, CII and USA}

If Robert Monks was mainly an ideologue who promoted institutional activism through his corporate-governance agenda, public pension funds were its practitioners, taking direct action against corporations. This they did by bringing to bear their rights and influence as shareholders, setting up umbrella organizations for their activism, and lobbying the U.S. government to change regulations in ways that would strengthen activism. They were "the most vocal advocates of corporate governance intervention" in the 1980s, and, conducting themselves as if they were rule-setters, they drafted codes of "best corporate governance practices" for their portfolio firms to adopt. ${ }^{42}$

From the 1950s, pension funds emerged as the biggest group of institutional investors in the United States because of the rapid expansion of business and government pension systems. By 1975 , they held $16 \%$ of U.S. corporate shares, four times more than mutual funds. Among them, private pension funds, though in aggregate much larger than public pension funds, were not interested in institutional activism. Most of them were run by business corporations on behalf of their employees, and it was unthinkable for their top managers to take activist positions against their own companies or against other companies in general. ${ }^{43}$ Unlike those of corporate pensions, stock investments of public pensions were not representing pensioners in the business sector and hence their managers were freer to take activist positions regarding their portfolio companies. The retirement benefits of their clients, public-sector workers, were also more or less guaranteed by the state or federal government, and they had relatively less sympathy with corporate-sector workers. This fact made them freer to favor shareholder interests over labor interests, when the two conflicted, even by advocating corporate restructuring led by corporate raiders that brought about massive layoffs and divestitures. ${ }^{44}$

\footnotetext{
${ }^{42}$ Cheffins (2013: 55).

${ }^{43}$ Corporate pensions held $13 \%$ of the market value of U.S. corporate stocks whereas public pensions held $3 \%$ of the stocks in 1975 . The corresponding figures were $20 \%$ and $5 \%$ respectively in 1985 and $18 \%$ and $8 \%$ in 1994 . (Blair 1995: 46, Table 2.1)

${ }^{44}$ Geltner (2013: 40).
} 
Moreover, public pensions mostly held onto defined-benefit (DB) plans and were very slow to move to defined-contribution (DC) plans-a transition that occurred with increasing momentum at business corporations during and after the 1980s. DB plans expose the employer to the potential for underfunding of their pension plans, whereas DC plans do not. Public pension fund administrators tried to avert this potential funding shortfall by using their collective shareholding power to seek higher yields from the stock market by strengthening shareholder activism. Public pension funds also had better access to regulatory authorities because they were regulated by states and exempted from the federal ERISA regime regulating private pension funds, and because a larger number of their administrators and board members were local administrators, politicians, and labor unionists. It was, therefore, relatively easy for them to support regulatory changes that would allow them to increase the ratio of stock to other holdings in their investment portfolios and to then use shareholder activism to seek higher yields on their portfolios. ${ }^{45}$

Among public pension funds, the California Public Employees' Retirement System (CaIPERS) emerged as the leader in institutional activism in the 1980s. As the largest institutional investor in the world, its size gave it the potential power to influence corporate boards and their resource-allocation policies. Moreover, because it had become one of the most expensive pension systems, CalPERS was under pressure to boost its investment yields by expanding its investments in stock and by becoming active in influencing its portfolio companies. ${ }^{46}$ Having introduced annual cost-of-living adjustments in 1968, two years later the fund adopted a very generous pension formula under which it paid workers who retire at age $6590 \%$ of their final salary for life. Following California voters' approval of a 1966 ballot measure, CalPERS had been allowed to invest up to $25 \%$ of its portfolio in stock, and in the early 1980 s it asked for permission to increase that limit to $60 \%$. Although the voters rejected this proposal, they approved a different one in 1984 that, while it "likewise let CaIPERS expand its investments [in stock]," it refrained from specifying a percentage limit and, for cosmetic purposes, put in "a

\footnotetext{
${ }^{45}$ Refer to Gelter (2013).

${ }^{46}$ In this context, Strine (2007: 7) observes as follows: "Interestingly, some of the demand for outsized returns has come from institutional investors - such as public pension funds - facing actuarial risks because of underfunding and past investment mistakes."
} 
clause that held CalPERS board members personally responsible if they didn't act prudently." 47 This permissive regime contrasted with the restrictions placed on other public pension funds, many of which had few or even no equities in their portfolios until the mid-1990s. ${ }^{48}$

From 1986, CalPERS started its major shareholder campaigns in close collaboration with the Council of Institutional Investors (CII), which had been set up the year before as an umbrella organization to espouse the collective interest of institutional investors. CalPERS led in drafting the list of companies characterized by "poor performance" to make it easy for CII member institutions to identify targets for their activist campaigns. ${ }^{49}$ It also created a shareholders' bill of rights establishing the principle that all shareholders have equal voting rights; demanded that corporations seek shareholder approval before paying greenmail or setting up poison pills; and called for a majority of outside directors to approve any extraordinary bonuses or other payments to corporate executives. CalPERS itself initiated, in 1989, a movement to change traditional proxy rules that led to the SEC's landmark proxy-rule amendments in 1992, which will be detailed below.

If Cll was crusading for shareholder activism among institutional investors, the United Shareholders Association (USA), launched by corporate raider T. Boone Pickens in 1986 and comprising more than 65,000 members, was ostensibly representing the interests of small shareholders. The USA put pressure on corporations by producing an annual "Target 50 " list of companies that were non-responsive to shareholders. ${ }^{50}$ It attempted to negotiate with target companies to modify their governance structures so that they would become more responsive to shareholder interests. It also mobilized its members' votes to sponsor proxy proposals if the target companies did not come to agreement with its demands. Although the USA claimed to represent retail shareholders, several large institutional shareholders, such as CalPERS, the

\footnotetext{
${ }^{47}$ Malanga (2013).

${ }^{48}$ Gelter (2013: 39).

${ }^{49}$ Individual activist pension funds also drafted their own list. For instance, CalPERS produced the list of the "Failing Fifty." Firms in the "Failing Fifty" are then analyzed further and the Investment Committee identifies approximately 12 targets and one corporate governance structure issue (for each target) that it will pursue in the form of a shareholder resolution. Shareholder resolutions have included creating shareholder advisory committees, changing the composition of the board of directors and its committees, and restructuring executive compensation. Refer to Smith (1996).

${ }^{50}$ Strickland et al. (1996: 320).
} 
College Retirement Equities Fund (CREF), and the New York City Employees Retirement System (NYCERS), sponsored proposals on the USA's behalf.

\subsection{The 1992 Proxy rule change: Allowing "free communication and engagement"}

While establishing proxy voting as a fiduciary duty of institutional investors, institutional activists pushed for changes in regulations governing the proxy system that would allow their collective voice to be heard more effectively by corporate management and the public. It was CalPERS that initiated the move in 1989 by sending a letter to the SEC requesting a comprehensive review of the proxy system. The letter "proposed forty-eight separate changes to the proxy rules", and CaIPERS's main purpose, it claimed, was "to even the imbalance between shareholders and management concerning the filing and processing of proxy materials." ${ }^{51}$

The CaIPERS petition was followed by those of other groups, including CII and USA. For instance, the USA sent a similar letter to the SEC arguing that "reform of the proxy process to allow shareholders a meaningful corporate governance role could forge a fundamental realignment of the now conflicting interests of management and shareholders. ... [S] uch realignment would maximize value on a constant basis, rather than through one-time restructuring transactions." ${ }^{\prime 52}$ This proxy-rule change was made during the period when corporate raiders were in retreat owing to the junk-bond market collapse, with such prominent figures in the junk-bond market as Ivan Boesky and Michael Milken being jailed. State governments had passed regulations limiting hostile takeovers and, with devices such as the "poison pill," corporations had strengthened their defenses against corporate raiders. The sudden change in the market for corporate control in the late 1980s made corporate raiders and other shareholder activists vigorous in lobbying to change the federal proxy regulations, as "one of the few remaining venues for effecting corporate management" ${ }^{53}$

\footnotetext{
${ }^{51}$ Sharara and Hoke-Witherspoon (1993: 336).

${ }^{52}$ Sharara and Hoke-Witherspoon (1993: 337).

${ }^{53}$ Calio and Zahralddin (1994: 466).
} 
After over three years' deliberation during which the SEC made two proposals and received comments from various groups and individuals in response, the SEC finalized the watershed amendments to its proxy regulations in $1992 .^{54}$ The fact that, in 1993 , immediately following the amendments' adoption, USA declared "mission accomplished" and disbanded testified to the significance of this change for shareholder activists. ${ }^{55}$ Why were the amendments so important?

It should be noted that traditional regulations on institutional investors were unambiguous about prohibiting the formation of investor cartels, defining communication among investors as a "proxy solicitation." ${ }^{56}$ It was therefore illegal for any shareholder to discuss company matters with more than ten other shareholders without first filing with, and obtaining the approval of, the SEC. The 1992 amendments, however, largely deregulated proxy communication, not only among investors but also with company management and the public. This change flew in the face of the whole spirit of the New Deal regulations, overturning them in the name of allowing "market forces to restore a better sense of balance to America's board rooms" through the freer flow of communication and engagement. ${ }^{57}$

The new rules loosened restrictions on public shareholders in three ways. First, those investing in a given company were now allowed to communicate freely with one another if each held less than $5 \%$ of its shares and had no special relationship to that company. In other words, they were permitted to form investor cartels within the $5 \%$ limit. ${ }^{58}$ Second, they were now allowed to "engage" freely with management without worrying about potential breach of accessing insider information. This freer engagement was expected to provide investors with more and better information about corporations and perhaps lead to "relationship investing." Third, they were in addition given the freedom not only to make public statements on proxy-

\footnotetext{
${ }^{54}$ SEC (1992); Sharara and Hoke-Witherspoon (1993); Bainbridge (2005).

${ }^{55}$ Blair (1995: 73).

${ }^{56}$ Refer to Section 1 of this Chapter.

${ }^{57}$ Calio and Zahralddin (1994: 466).

${ }^{58}$ But then as now, this limit did not really constrain investors, especially when they were holding shares in large public companies. Institutional investors have generally held less than $5 \%$ of the shares outstanding, with only a few amassing more than a 5\% share. To cite a recent example, as of April 21, 2016, there were only two institutional investors, Vanguard Group (9.9\%) and State Street Corp. (6.7\%), that held 5\% or more shares of Apple Inc. (http://www.nasdaq.com/symbol/aapl/ownership-summary).

${ }^{59}$ On definition and pros and cons of "relationship investing", refer to Blair (1995, ch.5).
} 
voting issues but even to announce their voting intentions without violating the proxy-filing requirements.

The SEC made it clear that it was removing itself from the job of proxy censorship because it believed that contestants in proxy voting "should be free to reply to [an opponent's] statement in a timely and cost-effective manner, challenging the basis for the claims and countering with their own views on the subject matter through the dissemination of additional soliciting material." ${ }^{60}$ Some institutional activists argued for the proxy-rule changes even in the name of removing restrictions on the constitutional right of free speech, and the SEC eventually concurred with the argument.

In 1999, the SEC added to the proxy rules new elements that fully liberalized communication. ${ }^{61}$ Investors were now allowed to conduct unlimited solicitation, not only among themselves but also with the public, including in the form of press releases, even if they abandoned proxy filing in the end. Oral communications were also freely permitted with no need "to be reduced to writing and filed." This rule change allowed investors to engage more freely with corporate management and the public without incurring any obligation to state their intentions in a document that is legally binding. ${ }^{62}$ In particular, this rule allowed activist shareholders "to gauge the level of support from other shareholders" before filing a proxy statement and thereby to "mitigate the risk of losing a costly proxy contest." ${ }^{63}$

\subsection{The 1996 NSMIA: Allowing unlimited "alternative investment" in hedge funds}

An impetus for the phenomenal growth of the hedge fund industry and the consequent rise of hedge-fund activism was provided by the 1996 National Securities Markets Improvement Act (NSMIA), which was part of financial market deregulation during the Clinton administration. According to David Dayen who delved into NSMIA's implications for hedge funds, the regulatory change, "largely unnoticed at the time" and "advanced with broad Wall Street support and

\footnotetext{
${ }^{60}$ Quoted in Briggs (2007: 687).

${ }^{61}$ Rule 14a-12.

${ }^{62}$ Briggs (2007: 689-690).

${ }^{63}$ Lu (2016).
} 
almost no resistance in Congress,"effectively allowed hedge funds to pool unlimited financial resources from institutional investors without regulations that would have required disclosure of the structure of their firms or prohibited overly speculative investments. ${ }^{64}$

To be exempt from regulation under the Investment Company Act of 1940 as a private fund, a hedge fund had to serve fewer than 100 "high-net-worth" investors, who were persons with a net worth of at least $\$ 1$ million or who had generated income of at least $\$ 200,000$ annually for the previous two years. ${ }^{65}$ However, Section 209 of the NSMIA modified the Investment Company Act of 1940 to remove the long-existing regulation on the number of clients, creating an exemption for an unlimited number of "qualified purchasers" that could include any individual investor with a net worth of $\$ 5$ million or more or any institutional investor with financial assets of \$25 million or more. ${ }^{66}$ The 1996 NSMIA therefore continued to treat hedge funds as private entities while granting them the ability to draw funds from a substantially larger pool of investors, especially from institutional investors.

As Figure 3 shows, it took only seven years after the enactment of NSMIA for hedge funds' assets under management (AUM) to increase more than tenfold, from \$118 billion in 1997 to over $\$ 1.2$ trillion in 2004. Since that time, it has more than doubled to over $\$ 3$ trillion in $2016 .{ }^{67}$ A main contributor to this explosive growth was investment by institutional investors following the 1996 NSMIA. According to Preqin Global Hedge Fund Report, about 5,073 institutional

\footnotetext{
${ }^{64}$ Dayen (2016).

${ }^{65}$ Hedge funds are notable (and definable) largely by their strategy of organizing outside existing financial regulations applicable to larger institutional funds. As they are organized in this way, hedge funds today have no real restriction on their size. Their major benefits include the ability to utilize performance pay schemes (" 2 and 20 "), $2 \%$ annual fee and $20 \%$ performance fee, as well as trading strategies considered too speculative and risky for institutional investors. Hedge funds and other private funds are structured specifically to avoid thresholds that would trigger certain disclosure rules and other regulations. For example, under the Securities Act of 1933 a hedge fund seeking to be a private (i.e., unregistered) fund cannot publicly solicit prospective clients, the rationale being that "private placement" attracts informed, experienced investors.

${ }^{66}$ Existing regulations under the 1934 Securities Exchange Act would force registration with the SEC when and if the total number of investors reached 500 or if total assets exceeded $\$ 10$ billion. In practice, then, the post-NSMIA environment created a "threshold" for hedge funds and an incentive to limit their population of investors to no more than 499 institutions or very wealthy individuals.

${ }^{67}$ While A.W. Jones' hedge fund managed approximately \$70 million in 1966 (over \$500 million in 2016 dollars), today there are several hedge funds managing in excess of $\$ 1$ billion. The largest hedge fund in the world today is probably Ray Dalio's Bridgewater Associates, with about $\$ 160$ billion under management.
} 
investors allocated funding to about 60 percent of hedge-fund assets in $2016 .{ }^{68}$ The leading sources of institutional funds are public and private pension funds and endowments, representing about 53 percent of the total assets of hedge funds. ${ }^{69}$

Figure 3. The growth of the hedge-fund industry, 1997-2016

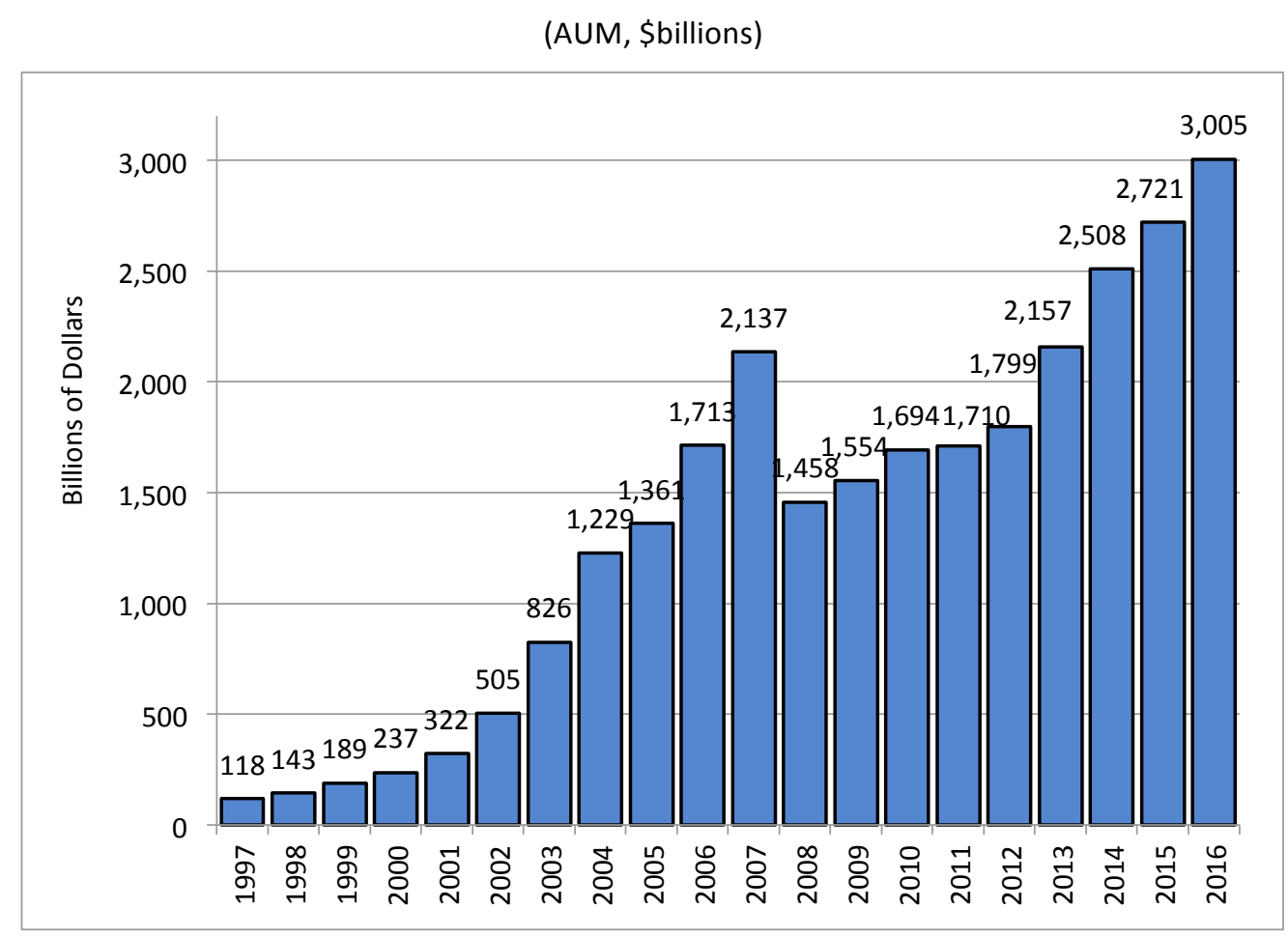

Source: BarclayHedge.

The rise of hedge-fund activism was a phenomenon that reflected the explosive growth of the overall hedge-fund industry that began in the 1990s. It is estimated that the combined AUM of activist hedge funds increased more than tenfold in six years, from \$15 billion in 1997 to $\$ 117$ billion in 2003, and then more than quadrupled in next 11 years, to reach $\$ 507$ billion in 2014, as Figure 4 shows. $^{70}$

\footnotetext{
${ }^{68}$ Preqin (2016).

${ }^{69}$ For instance, one of every five university endowment dollars is now invested in hedge funds (The National Association of College and University Business Officers (http://www.nacubo.org/Research/Research_News/2013_Endowment_Study_Final_Report_Released.html.) 70 Lazonick and Shin (2018 forthcoming). Following the SEC's (2017) convention of including "distressed/restructuring" assets and "risk arbitrage/merger arbitrage" assets in "event-driven" assets, Lazonick
} 
Figure 4. The expansion of activist hedge funds, 1997-2016

(AUM, \$billions, \%)

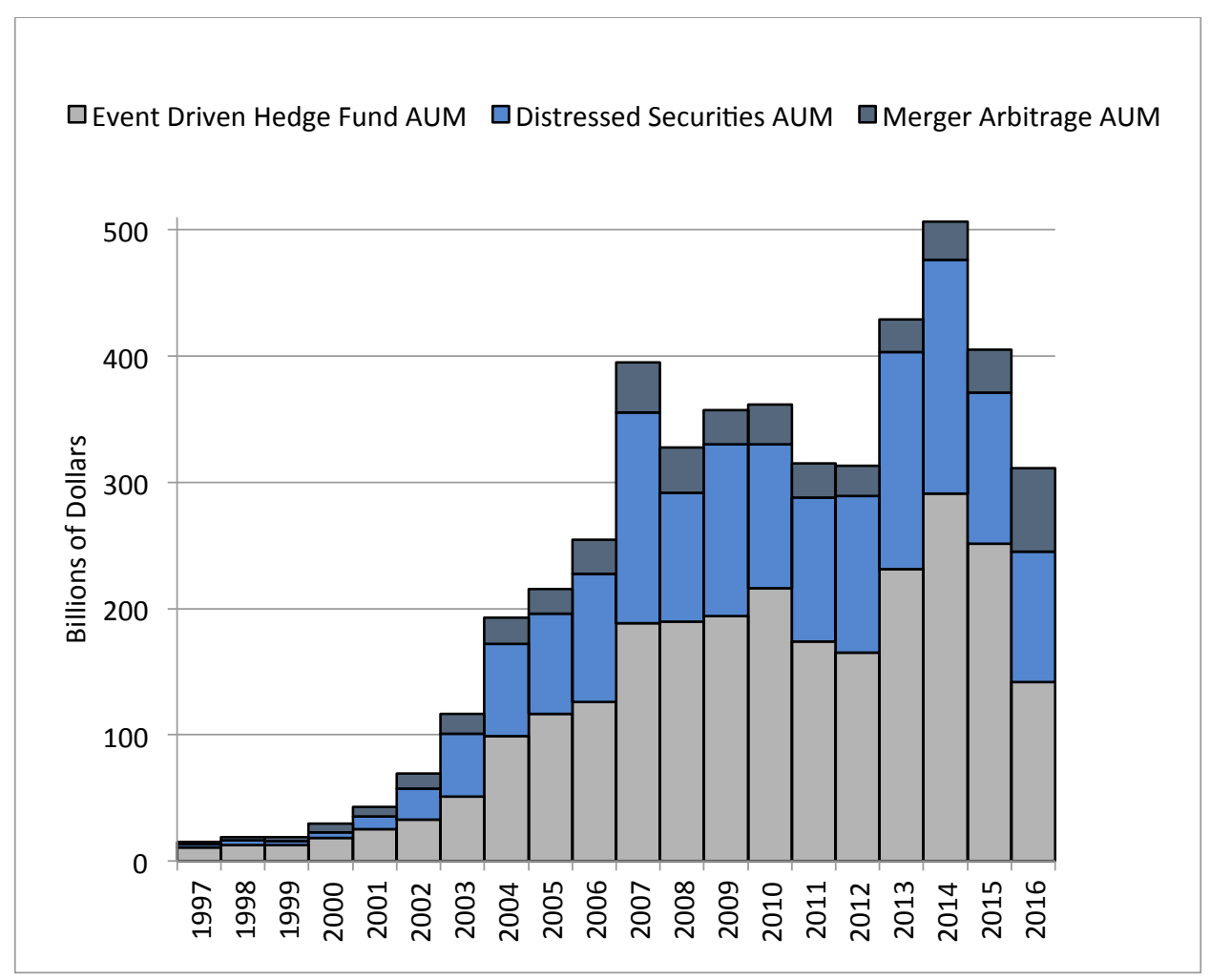

Source: BarclayHedge.

The incidence of activist campaigns and their success ratio have also increased sharply. 13D filings with the SEC are often used as a proxy for activist campaigns because Schedule 13D must be filed when an investor accumulates a 5 percent-or-greater share of a corporation's outstanding stock, which also triggers a requirement that the investor disclose the purpose of its accumulation. ${ }^{71}$ The incidence of 13D filings for activist purposes increased from 10 in 1994

and Shin estimated the AUM of activist hedge funds by combining "event-driven" assets, "distressed" assets] and "merger arbitrage" assets in BarclayHedge data above. The numbers then become similar to those of the SEC [where the overall size of "event-driven" assets is $\$ 430$ billion. Foley (2016), Foley and Johnson (2014), Marriage (2013), and Chandler (2016) also equate activist assets with the overall assets devoted to an event-driven strategy. The overall trend in the growth of hedge fund activists' AUM is more or less the same in those estimates.

${ }^{71}$ For instance, an investor should disclose whether it demands a change in management, stock buybacks or special dividends, a seat on the board, etc. In contrast, investors file schedule $13 \mathrm{G}$ when assuming a passive stake of $5 \%$ or more in a publicly traded corporation. 
to 212 in $1997 .^{72}$ It then increased to 353 in 2008. After a sharp reduction during the Global Financial Crisis of 2008-2009, the incidence recovered to 355 in 2015. In 2003, 39 percent of proxy fights for board seats resulted in settlements or victories for activists. This success rate soared to 60 percent in $2013 .^{73}$

\section{Institutional activism gone astray}

For over three decades since institutional activism began in the United States, there is no empirical evidence to establish that it contributed to improving corporate performance in the medium or long run although it moved stock prices in the short run. Instead, there is strong evidence that it resulted in predatory value extraction from corporations and contributed to the worsening income distribution and disappearance of middle-income class in the United States. ${ }^{74}$ Even Monks admitted, toward the end of his long career as a corporate-governance activist, "It's broke," "Ownership is a fiction, governance a mirage". ${ }^{75}$ Or as he also put it: "The fundamental dynamics of Corporate Governance have been diluted into virtual meaninglessness." ${ }^{\prime 76}$

Figure 5 broadly shows the effect of institutional activism on corporate finance. During the heydays of corporate raiders in the 1980s, net outflow of funds from corporations became prominent for the first time during the postwar period. ${ }^{77}$ Since the rise of hedge-fund activism

\footnotetext{
${ }^{72}$ The SEC requires purchasers of corporate stock to file form 13D within 10 days of the date on which their ownership stake crosses the $5 \%$ threshold. The form requires disclosure of the intent of the acquisition of stock. ${ }^{73}$ Laide (2014).

${ }^{74}$ For details on the empirical research, refer to Lazonick and Shin (2018 forthcoming, chapter 7). For instance, Karpoff (2001) concludes as follows: "Most evidence indicates that shareholder activism can prompt small changes in target firms' governance structures, but has negligible impacts on share values and earnings. To be sure, some empirical results are mixed. But much of the disagreement among researchers reflects differences in the metrics emphasized. Researchers emphasizing changes in target firms' governance structures tend to characterize shareholder activism as a 'successful' tool to improve firm performance. Most of those emphasizing changes in share values, earnings, or operations, in contrast, characterize shareholder activism as having negligible effects on target companies." Similar conclusion were made by Gillan and Starks (2007); Bainbridge (2005); Becht, Franks, Grant and Wagner (2015); Briggs (2007); Cheffins and Armour (2011); Coffee and Palia (2015).

${ }^{75}$ Monks (2013).

${ }^{76}$ Monks (2015).

${ }^{77}$ Net equity issues are new corporate stock issues minus outstanding stock retired through stock repurchases and M\&A activity.
} 
from the middle of the 1990s, the trend of outflow of funds from corporations strengthened even more although the trend was reversed briefly twice in the early 2000s during the burst of dot.com bubbles and in the late 2000s during the Global Financial Crisis due to the need to recapitalize crisis-hit corporations. The net outflow of funds has continued to increase both absolute and relative terms: During 1976-1985, it was $\$ 290.9$ billion amounting to $0.4 \%$ of GDP. It then increased to $\$ 1,002.5$ billion during $1986-1995$ (1\% of GDP), to $\$ 1,524.4$ billion (1.09\% of GDP) during $1996-2005$, and to $\$ 4,466.6$ billion (2.65\% of GDP) during $2006-2015$. $^{78}$

Figure 5. Net equity issues, U.S. nonfinancial companies, 1946-2016

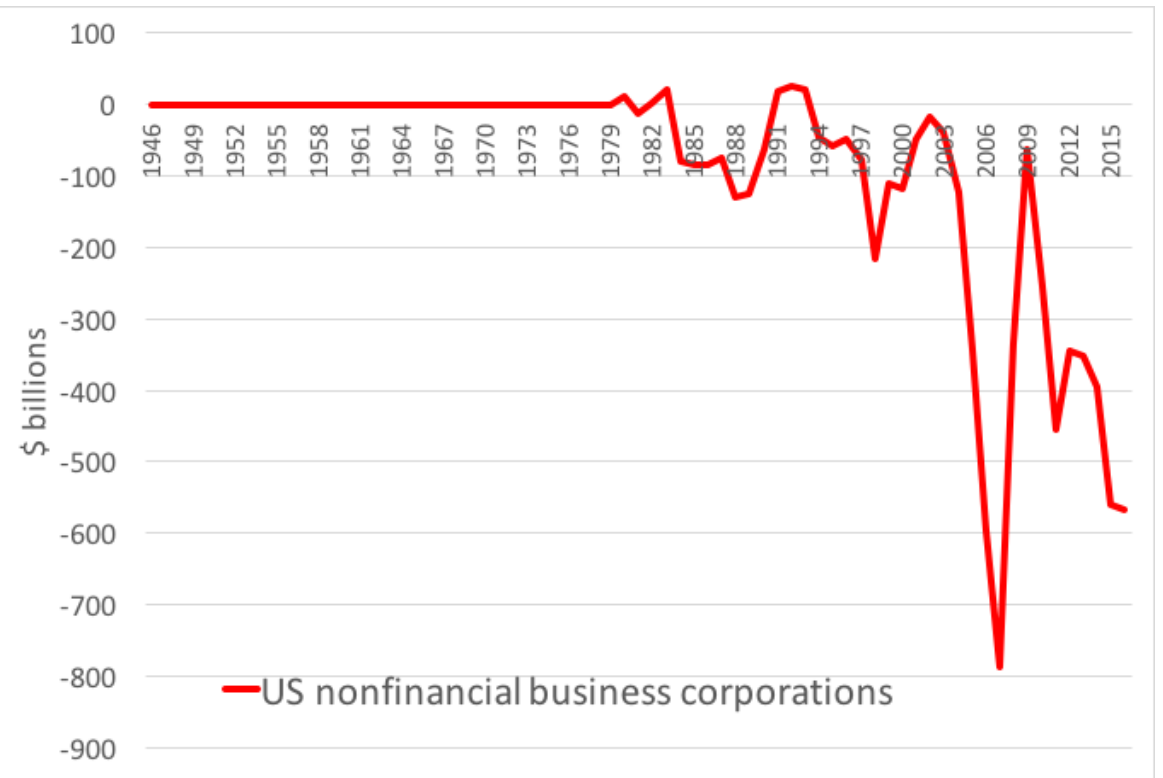

Source: Board of Governors of the Federal Reserve System, Federal Reserve Statistical Release Z.1, "Financial Accounts of the United States: Flow of Funds, Balance Sheets, and Integrated Macroeconomic Accounts," Table F223: Corporate Equities, June 8, 2017, at https://www.federalreserve.gov/releases/z1/current/.

It has now become a "new normal" that many of America's largest corporations routinely distribute more than 100 percent of net income to shareholders, generating the extra cash by reducing cash reserves, selling off assets, taking on debt, or laying off employees. For instance, the 459 companies in the S\&P 500 Index in January 2016 that were publicly listed over the ten-

\footnotetext{
${ }^{78}$ For details, refer to Lazonick and Shin (2018 forthcoming); Lazonick (2015; 2016).
} 
year period 2006-2015 expended \$3.9 trillion on stock buybacks, representing 53.6 percent of net income, plus another 36.7 percent of net income on dividends. Much of the remaining 9.7 percent of profits was held abroad, sheltered from U.S. taxes. ${ }^{79}$ Why has institutional activism gone astray?

\subsection{Uninterested and incapable, but strong institutional investors}

An important supposition of institutional activism is that institutional investors have the capability, interest, and legitimacy to fix corporate problems. However, this assumption is seriously flawed. More than anything else, institutional investors are speculators and/or savers whose professional capability primarily lies in portfolio management, which includes stockpicking, market timing, and tracking stock-price movements. These stock-trading capabilities are very different from the managerial capabilities required for value creation by producing low-cost and/or high-quality goods and services, as New Deal policy-makers already made it clear nearly a century ago when introducing regulations on institutional investors. By virtue of the work that they do, fund managers are hardly competent or dedicated fixers of corporate difficulties, especially in relation to operational performance.

Moreover, characteristics of institutional shareholding evolved far away from the ideal of shareholder activists. They maintained the outdated outlook of "dispersed ownership" and portrayed institutional investors as weak "minority shareholders" who did not have effective means of voicing their concerns to "all-powerful" corporate management. They then sought to strengthen the power of institutional investors against management by changing regulations so that they can easily aggregate their voting power by allowing de facto investor cartels, with "free communication and engagement".

Institutional shareholding surpassed 32\% mark in 1980 and approached 45\% in 1990, however, already making institutional investors the most dominant corporate shareholders and it was certain that the trend would only strengthen later. Moreover, institutional shareholding has been extremely concentrated in the hands of relatively few large institutional investors. In

\footnotetext{
${ }^{79}$ For details, refer to Lazonick and Shin (2018 forthcoming); Lazonick (2015; 2016).
} 
mid-2016, for example, the 25 largest institutional investors held stock valued at \$12.3 trillion, which was $56 \%$ of the value of all publicly held equities in the United States. Even among these 25 , the degree of concentration is remarkable. The 10 largest institutional investors held $\$ 9.3$ trillion in public stocks (42\%), with their average shareholding over 60 times that of the $11^{\text {th }}$ through $25^{\text {th }}$ largest institutional investors. And nearly one-third (31\%) of total U.S. public stocks, with a total value of $\$ 6.8$ trillion, was concentrated under the control of the five largest institutional investors (Table 1). The U.S. stock market is dominated by what Vanguard founder John Bogle has called the "King Kong of investment America". ${ }^{80}$

Table 1. Concentration of Shareholding among Institutional Investors (2016)

\begin{tabular}{lll}
\hline Rank & Institutional Investors & Total Holdings (\$ billion) \\
\hline 1 & BlackRock, Inc. & 2,044 \\
2 & Vanguard Group, Inc. & 1,553 \\
3 & Fidelity Investments & 1,272 \\
4 & State Street Corporation & 1,090 \\
5 & Capital Group Companies, Inc. & 857 \\
6 & T. Rowe Price Group, Inc. & 814 \\
7 & JPMorgan Chase \& Co. & 456 \\
8 & The Bank of New York Mellon Corporation & 410 \\
9 & Wellington Management Group LLP & 389 \\
10 & TIAA-CREF & 373 \\
\hline & Top 5 Holders & $6,818(31 \%)^{*}$ \\
\hline & Top 10 Holders & $9,261(42 \%)$ \\
\hline & Top 25 Holders & $12,307(56 \%)$ \\
\hline
\end{tabular}

Source: Capital IQ

* Percentage of total equity assets in the U.S.

\footnotetext{
${ }^{80}$ Bogle (2005: 76).
} 
These "King Kong" investors have amassed unprecedented voting power over individual companies. For instance, BlackRock, the largest institutional investor in the world with \$4.7 trillion of AUM in mid-2016, held 5\% or more of the outstanding shares in each of 2,610 companies around the world. Vanguard and Fidelity, the second- and third-largest institutional investors, held $5 \%$ or more of the shares in each of 1,872 companies and 1,173 companies, respectively (see Table 2). In an article entitled "The Giant of Shareholders, Quietly Stirring", the New York Times reported in 2013 that BlackRock was "the single largest shareholder in one of every five U.S. companies including Exxon Mobil and Chevron; AT\&T and Verizon; JPMorgan Chase and Citigroup; GE; and more than 800 others. It also holds $5 \%$ or more shares of 1,803 U.S.-listed companies, about $40 \%$ of roughly 4,300 total U.S.-listed companies." ${ }^{\prime 1}$ The dominance of the largest institutional investors is stronger over larger companies than smaller ones as they prefer to hold larger companies that have bigger impact on index. According to Jan Fichtner and others, if restricted to the S\&P 500 companies in 2015, "the Big Three [BlackRock, Vanguard and State Street] combined constitute the largest owner in 438 of the 500 most important American corporations, or roughly in 88 percent of all member firms." ${ }^{\prime 2}$

Table 2. Number of Companies in which an Institutional Investor Has a 5\% or Greater Stake (2016)

\begin{tabular}{lc}
\hline \multicolumn{1}{c}{ Institutional Investor } & $\begin{array}{c}\text { Number of global } \\
\text { companies }\end{array}$ \\
\hline BlackRock, Inc. & 2,610 \\
Vanguard Group, Inc. & 1,872 \\
Fidelity Investments & 1,173 \\
Capital Group Companies, Inc. & 465 \\
Wellington Management Group LLP & 439 \\
T. Rowe Price Group, Inc. & 414 \\
& \\
& \\
\hline 3). &
\end{tabular}


JPMorgan Chase \& Co.

State Street Corporation

The Bank of New York Mellon Corporation

TIAA-CREF
191

178

98

24

Source: Capital IQ

Their voting power over individual companies is more remarkable when we consider the fact that these largest of institutional investors are the most diversified stock investors in world history. Leading mutual funds and pension funds rely heavily on holdings in index funds and exchange-traded funds (ETFs), by which they effectively "own the market", as the number of portfolio companies in a fund sometimes exceeds 10,000. Even though their portfolios are often characterized as "excessive diversification," they are still the single largest shareholders in a great number of public companies.

At the same time, the portion of short-term trading has increased dramatically. On the New York Stock Exchange, high-frequency trading (HFT) currently accounts for about half of the total trading volume after peaking at over $70 \%$ in 2008 . The average stock holding period was shortened from 57.1 months in 1980 to 15.4 months in 2000 , and 4.8 months in $2009 .{ }^{83}$ The financial market is currently flooded with reports such as "Algorithms Take Control of Wall Street," "A.I. Controls the Stock Market," "The U.S. Stock Market Belongs to Bots." ${ }^{84}$ JPMorgan Chase estimated in 2017 that $\mathrm{Al}$, including indexing and HFT, controls about $60 \%$ of stock trading in the United States and discretionary equity trading accounts for only about $10 \%$ of the total trading. ${ }^{85}$ It is impossible to expect these Als to behave as responsible and capable "corporate citizens."

This change of the shareholding structure reveals the schizophrenia of shareholder activists. In their zeal for activism, they envisioned a new world where institutional investors become more active and capable of intervening in corporate management. But institutional investors have evolved toward being less interested and less capable in engagement and proxy voting.

\footnotetext{
${ }^{83}$ Wong (2010).

${ }^{84}$ Salmon and Stokes (2010; Danneman (2017)); Burger (2017).

${ }^{85}$ Burger (2017).
} 
Ironically, the legitimacy of institutional investors' engagement and proxy voting has eroded as their power over corporations has increased. In denial of this new reality and, at the same time, sensing and exploiting the growing power of institutional investors, shareholder activists have only pressed for strengthening activism by aggregating power of already powerful institutional investors.

\subsection{Misdirected compulsory voting: Power to proxy advisory firms}

Monks invoked the concept of "citizenship" from political democracy when he pushed for compulsory voting of institutional investors. Like him, most advocates of shareholder democracy have tended to employ analogies taken from political democracy. But Monks critically erred in using this analogy because compulsory voting is not a norm of political elections in most countries. He did not examine why it is not so or what its implications are for shareholder democracy. More importantly, he failed to assess, what real effects imposing compulsory voting as a fiduciary duty would have on the behavior of institutional investors.

\section{(1) Incorrect and arbitrary analogy with political voting}

In a political election, compulsory voting certainly has its pros and cons. It can have the positive effect of augmenting the power of representation by increasing the turnout of voters at the ballot box. However, it can have negative effects on an election outcome because it increases blank, randomly marked, and spoilt ballots from voters who are not interested in the election and do not know about the candidates. These uninterested voters are also more prone to cast their votes in response to hot-button issues of the day or political scandals, rather than trying to align their voting with ideological or policy preferences. ${ }^{86}$

The political reality around the world is that, whatever the theoretical balance of pros and cons, there are only a few countries that have adopted a compulsory voting system. In 2015 there were ten countries, including Australia, Brazil, and Singapore, where compulsory national

\footnotetext{
${ }^{86}$ Refer to Birch (2009); Brennan and Hil (2014); Singh (2015).
} 
voting was in effect and two local governments that had made voting compulsory. ${ }^{87}$ Most countries consider voting as a right, not as a duty that they should enforce on their citizens. Many countries also take the position that to abstain from voting is also an expression of political preference that should be allowed in accordance with the constitutional right of freedom of speech. The fact that most countries do not adopt compulsory voting in political elections tells us that they are much more concerned with its cons than with its pros.

Yet advocates of compulsory voting for institutional investors - including Monks and other corporate governance activists, as well as regulatory authorities like the SEC and the DOL - in adopting this position, presented only its potential pro, without considering or presenting either its cons or what the net effect of those pros and cons would be. If one looks into the nature and process of proxy voting by institutional investors, it is not hard to find that the cons of compulsory proxy voting are a lot more pronounced than those of compulsory political voting.

In a political election, the secret ballot is the norm: Voters are guaranteed secrecy of their ballots and not compelled to explain their voting decisions. In this situation, the negative effects of voting at random can be mitigated by the law of large numbers. In proxy voting, however, institutional investors are required not only to declare how they voted but also to provide justification for their voting decisions. This means that uninterested institutional investors are obligated to create justifications for their voting decisions, to purchase those justifications from third parties, or both. Even those who are interested in voting may decide to vote against their own preferences if strong public backlash against their voting decisions appears likely.

Moreover, there is no room for conflict of interests in political voting (unless one can divide a person) whereas proxy voting is wide open to conflict of interests. In fact, the phenomenal growth of both the capital market and institutional investment has greatly lengthened and complicated the chain of intermediaries involved in institutional investing. In pension-fund investments, for instance, the chain extends from pensioners to pension administrators, pension investment advisers, funds of funds, external asset managers, and others. The relation

${ }^{87}$ Wikipedia, https://en.wikipedia.org/wiki/Compulsory_voting\#Current_use_by_countries. Accessed on April 16, 2016. 
among those intermediaries has also become very complex because, even within one mutual fund, there are numerous sub-funds. Considering the length and complexity of this chain, it is questionable whether those at the end of the chain would really exercise voting rights over corporations on behalf of the customers who had put money into their custody. Far detached from the original customers, institutional investors have opportunity to cast their votes in their own interest rather than in the interest of those whose proxies they hold. This possibility becomes greater if the original customers have little power to replace their intermediaries, as typically is the case with public pension funds.

Nonetheless, the SEC expressed naïve expectation about the benefits of compulsory proxy voting in the "Final rule" in 2003 and this stance has not changed so far:

"Although we recognize that compliance programs, including proxy voting programs, may require advisers to expend resources that they could otherwise use in their primary business, we expect that the rules and rule amendments may indirectly increase efficiency in a number of ways. Advisers would be required to carry out their proxy voting in an organized and systematic manner, which may be more efficient than their current approach. Requiring all advisers with voting authority to adopt proxy voting policies and procedures, and meet recordkeeping requirements, may enhance efficiency further by encouraging third parties to create new resources and guidance to which industry participants can refer in establishing, improving, and implementing their proxy voting procedures." $^{\prime 88}$

The SEC 's position is based on the optimistic expectation of institutional investors' developing analytic capabilities that would enable them to make voting decisions "in an organized and systematic manner," and that "third parties" would be competent and objective in providing advice. Reality has shown this optimism to have been unfounded. Far from taking compliance seriously, the largest institutional investors, especially index funds, limited their efforts to setting up skeletal research units that barely paid lip service to the new rule. Nor did

\footnotetext{
${ }^{88}$ SEC (2003).
} 
the "third parties", the proxy-advisory firms, equip themselves adequately for their task; still, they exert undue power over voting decisions of institutional investors, and thereby over corporations. In addition, they have a serious potential for conflicts of interest, as will be detailed below.

\section{(2) "Corporate-governance teams" in large index funds: Lip-service voting organizations}

Most large mutual funds had rarely taken part in corporate voting before it became compulsory in 2003. That was a natural and, in my view, appropriate position, considering the fact that the larger portion of their assets was held in index funds. Simply to track index movements rather than to research individual companies constitutes the critical competitive edge that has enabled mutual funds to charge very low management fees and, consequently, to rapidly increase their AUM.

When the SEC ruled proxy voting to be among their fiduciary duties, the mutual funds initially relied heavily on recommendations from proxy-advisory firms; in other words, they "purchased" proxy-voting decisions and related justifications. However, criticisms soon emerged of both this practice and the proxy-advisory firms. Large mutual funds were therefore under pressure to demonstrate to policy-makers, their own customers, and the public that they were dutifully fulfilling this new fiduciary obligation. Many of them then adopted the two-

pronged approach of separating the voting decisions of the active funds and passive funds under their management, and of setting up a corporate-governance team or stewardship team for the latter.

BlackRock provides an illuminating case in this regard. In 2014, its index-related funds amounted to $\$ 3.3$ trillion, constituting about $70 \%$ of the total AUM. BlackRock divides its voting decisions between active-management funds and passive-management funds. The proxy decisions of the former are made primarily by the fund managers in charge of the portfolio firms concerned. In contrast, the proxy decisions of the latter are under the control of its corporate-governance team. To outsiders, this corporate-governance team is portrayed as being equipped to make informed voting decisions and to engage professionally with portfolio 
companies. The reality, however, lies far from this rosy picture. In the 2012 proxy season, the team consisting of only 20 people voted on 129,814 proposals at 14,872 shareholder meetings worldwide. ${ }^{89}$ The only feasible way to deal with so many voting decisions with such limited personnel is to apply some general corporate-governance metrics rather than to examine the concrete contexts of individual companies' voting issues.

The New York Times thus described the team's decision-making as "the corporate governance equivalent of speed dating" and reported as follows: "These analysts have a language of their own, casually throwing around terms like 'overboarding,' for when directors serve on multiple boards, possibly spreading themselves too thin; 'engagement,' when a problem reaches a critical stage and merits a visit from a BlackRock analyst; and 'refreshment', when engagement doesn't work and a director needs a heaveho." ${ }^{90}$ A glance at the internal operation of the corporate-governance team only strengthens the suspicion that keeping this team as small as possible is a cheap, and probably the only, option for the largest index funds to demonstrate to the public that they are carrying out their fiduciary duty of proxy voting sincerely. ${ }^{91}$ In this sense, one may say that corporate governance teams are "lip-service" units that have resulted from the imposition of compulsory voting on institutional investors. ${ }^{92}$

\section{(3) ISS, the proxy-voting monster: Its inadequacy, bias, and illegitimate power}

\footnotetext{
${ }^{89}$ Loomis (2014).

${ }^{90}$ Craig (2013).

${ }^{91}$ BlackRock later changed its name to 'Investment Stewardship Team' and increased the number of its staff to about 31 in 2017 ('BlackRock, Vanguard and State Street bulk up governance staff', Financial Times, January 29, 2017. https://www.ft.com/content/657b243c-e492-11e6-9645-c9357a75844a). But this was only in accordance with the increase in its AUM. At the end of 2017, BlackRock's AUM was \$6.28 trillion.

92 Some researchers suppose that the largest index funds pursue certain "active strategies" for profit maximization by coordinating their votes across portfolio companies. For instance, Schmalz $(2017 ; 2018)$ argues that these "common owners" discourage competition among the portfolio companies in order to maximize combined profits of portfolio companies. Similarly, Fichtner et al. (2017: 23) mentions as follows: "passive index fund managers arguably have little interest in fierce competition between their co-owned corporations, because this constitutes a zero-sum (or even negative-sum) game for them. Rather, they have industry or market-wide interests." It will require further research to determine this behavior of index funds. However, it is doubtful to me that corporate governance teams or stewardship teams of those largest mutual funds have capabilities to stretch their corporategovernance-related agenda to such interventions in their portfolio companies. Considering their minimal size, it looks more natural to think that they simply lack capability and interest to intervene in individual corporate affairs in such systematic manners.
} 
Nor have the abilities of proxy-advisory firms turned out to be much more impressive than those of the internal corporate-governance teams of the largest institutional investors. ISS currently controls $61 \%$ of the proxy-advisory market, while Glass, Lewis and Co. controls $35 \%$, making the market a virtual duopoly. In its influence over large institutional investors, however, ISS is unmatched, having claimed at one point to be advising "24 out of the top 25" mutual funds and "17 out of the top 25 " pension funds. ${ }^{93}$ Considering the dominance it has enjoyed in the proxy-advisory market, focusing exclusively on the case of ISS will suffice for our purposes here.

Although ISS currently recommends yes-or-no decisions on more than 9.6 million ballots representing 3.7 trillion shares a year in 115 countries, it only has 1,100 employees, its administrative staff included. ${ }^{94}$ How could it have developed capacity and expertise to make so many informed voting decisions on such diverse issues in so many companies around the world? Company managements and shareholders bring to shareholder meetings proposals mainly because they are controversial. It is not difficult to draft a reasoned report just by comparing the pros and cons of such controversial issues. But it is very difficult to write a report that determines a clear "yes" or a clear "no" on such issues. It strains credulity to think that ISS, with so few employees, has been able to assemble the complex, high-level expertise capable of making authoritative recommendations on so many issues. In reality, ISS tends to apply general and mechanical corporate-governance metrics to its voting recommendations, just as the largest index funds' corporate-governance teams tend to do. Institutional investors, its major customers, actually did not care about or rely upon ISS before they were required to vote.

For most index funds, just following the recommendations of proxy-advisory firms is the most convenient way to fulfill their fiduciary duty "because they can't justify to shareholders why they invest in their own analysis." ${ }^{\prime 95}$ Only the largest index funds, such as BlackRock and Vanguard, set up in-house corporate-governance teams. Lesser index funds have no alternative

\footnotetext{
${ }^{93}$ Rose (2007).

${ }^{94}$ ISS website. Accessed on May 4, 2018.

${ }^{95}$ Bew and Fields (2012: 15). In this context, Winter (2011: 10) argues that voting by institutional investors following proxy advisory firms' recommendations "is essentially a form of empty voting" because "[t]he exercise of the voting right is determined largely by proxy advisors who do not have a shareholding interest themselves."
} 
but to rely heavily on proxy firms' advice. Even many active funds tend to follow the recommendations of proxy-advisory firms; combing through proxy firms' analyses and voting recommendations is a normal first step for fund managers. In addition, an internal convention at most institutional investors dictates that, if fund managers want to go against proxy firms' recommendations, they provide a lengthy report to their superiors to justify their decisions something they don't need to do if they simply go along with the recommendations. Going against proxy firms' recommendations thus requires courage and effort on the part of fund managers who are busy attempting to make profitable trades for the portfolios they manage. In this respect, the root of the power and influence of ISS is not really the quality of its work, but rather the convenience it provides to institutional investors by lightening the burden of performing the unwanted obligation of voting proxies.

Moreover, proxy firms are wide open to conflicts of interest because, as unregulated private business entities, they are responsible to nobody except their own businesses. They normally combine proxy-voting advisory services with consulting services. When there is a proxy contest between one of their customers and a non-customer, it is hardly difficult for them to side with their customer, packaging their support as an "objective" assessment. As private and unregulated entities, there is no way for outsiders to determine whether the voting recommendations of the proxy firms were made objectively or shaped to serve their own business interests.

There is also a tendency for proxy firms to provide voting advice that reflects the investment philosophy of their owners. Set up by corporate-governance activist Robert Monks, ISS would be likely to side with an activist fund in a controversy pitting such a fund against company management. The current owner of ISS is Vestar Capital, a private-equity fund that was founded by corporate raiders from First Boston's leveraged-buyout team. It would be only natural for ISS to support activist hedge funds when they have proxy battles with industrial companies.

In effect, compulsory voting for institutional investors has given ISS illegitimate power. Officially, it is only an "advisory" firm lacking any legitimate basis whatsoever for exerting influence on major corporate decisions of the kind that must be approved in shareholder 
meetings. Its influence cannot be ignored, however: A negative recommendation by ISS on a management proposal has been found to reduce the support of institutional investors by at least $13.6 \%$ and, at most, by $20.6 \% .{ }^{96}$ Corporate executives have to take a two-digit percentage difference very seriously, as it is often the case that the eventual voting outcome is decided by a difference of less than $10 \%$ in shareholder voting. Peter Iliev and Michelle Lowry report that over $25 \%$ of mutual funds "almost entirely" rely on ISS recommendations when they cast votes. ${ }^{97}$ It is therefore not an exaggeration to say that "[powerful] CEOs come on bended knees to ISS to persuade the managers of ISS of the merits of their views." 98

The illegitimate power of proxy firms arose partly because of the proxy-advisory market's being a duopoly and because, even between its two members, ISS is easily the dominant one. If there were a number of proxy-advisory firms with similar reputations and if institutional investors could choose from among their diverse recommendations, their service might be defined as - and confined to - "advice". However, when the imposition of compulsory voting made it necessary to fill the vacuum of institutional votes that had previously existed, the larger part of this job fell to ISS, upon which nobody had conferred legitimate power to influence voting decisions in the corporate arena. ISS is a monster created by compulsory voting. No corporation anywhere in the world sends ISS a formal invitation to take part in its shareholders' meeting, but it effectively attends these meetings and casts votes. Nobody dares to expel ISS for exercising illegitimate influence on voting outcomes of the meeting. Monks may not have been successful in achieving his activist agenda, as he has admitted, but there is no doubt that he is a successful entrepreneur who created the voting monster no one could ever have imagined.

\footnotetext{
${ }^{96}$ Bethel and Gillan (2002: 30).

${ }^{97}$ Iliev and Lowry (2015).

${ }^{98}$ Strine (2005).
} 


\subsection{Consequences of "free communication and engagement"}

In bringing about the 1992 proxy-rule amendments, shareholder activists also employed an analogy from political democracy. They portrayed corporate management as autocrats who ignored popular demands for freedom of speech and freedom of assembly while installing strict censorship in the form of proxy-filing procedures that, they charged, unfairly favored management. In contrast, they portrayed themselves as endeavoring to realize a "true shareholder democracy" by abolishing the censorship and thus obtaining the right of free communication and engagement. They then justified the proxy-rule changes by arguing that they would correct the imbalance between shareholders and management and bring about a more efficient market outcome.

However, such expectations are based on the critical assumption that freer and easier exchange of information has an efficiency-enhancing effect in the market, an assumption that follows from conventional economic models of competitive markets, which are in turn based on the assumption that interaction among players who have equal capability and equal access to information is the key to ensuring an efficient outcome. But markets in general, and the stock market in particular, do not function according to this neoclassical model. Markets may be unduly influenced by strong "movers and shakers," and the stock market in particular is prone to manipulation. As it turned out, the very practices that the traditional regulations were meant to deter by preventing free communication and engagement, "fraud or deceit" and "manipulative or deceptive devices or contrivances", became more widespread because of the proxy-rule changes and compulsory proxy voting. ${ }^{99}$

Above all, the "wolf-pack phenomenon" - sudden concerted campaigns of hedge funds against their target companies-has become a new normal since the 1992 proxy-rule changes. Wolf packs can only be seen as de facto investor cartels. In conventional economics, cartels are considered prime obstacles to realizing the efficient allocation of resources, and they are therefore regulated heavily in most countries with capitalist economies. The existence of unregulated wolf packs is testament to the fact that with the proxy-rule changes the SEC

\footnotetext{
${ }^{99}$ Refer to Section 2 of this paper.
} 
effectively gave up its duty as a market regulator, employing the rhetoric of promoting "market efficiency" to hide this failure.

The SEC might have naively thought that freely allowing investor cartels made up of shareholders, none of which held less than $5 \%$ of the target company's stock, would not undermine "market efficiency". However, in light of the broad dispersion of shareholding in big public companies, those with a $5 \%$ stake can easily exert a strong influence on management. Moreover, the $5 \%$ rule is easily circumvented through the formation of wolf packs. It is now a common practice for hedge funds to collaborate among themselves or with other investors around a target company and coordinate their strategies and tactics. Even if each of those collaborating may hold less than $5 \%$ of the target company's outstanding shares, their combined stake can easily elevate them to the status of controlling shareholders. It is also possible for one lead wolf to take a share exceeding $5 \%$, make public its intention of campaign, and then recruit other, unidentified, wolves, each holding less than $5 \%$ shares, to support its attack. In the fight over control of Barnes and Noble, for example, the lead activist investor held an $18.7 \%$ stake in the company, but it turned out that the actual wolf pack controlled a $36.14 \%$ stake. ${ }^{100}$ In the campaign that forced the sale of Knight Ridder, "[w] hat started out as a 19\% stake effectively grew to $37 \%$ in just 48 hours. The campaign succeeded almost instantly." ${ }^{101}$ Moreover, making it easier to form wolf packs in turn made it easier to manipulate the market through the "wolf-pack effect". Upon the announcement or leaking of information about the formation of a wolf pack, the stock market generally reacts positively. For instance, an international study on the wolf-pack effect reports "abnormal announcement returns of 7\% for the United States during a $(-20,20)$ day window" and of " $6.4 \%$ and $4.8 \%$, respectively", for Europe and Asia. ${ }^{102}$ Those in the pack can easily develop trading strategies in advance because they exclusively know when they will trigger the wolf-pack effect. The market will also react to the way in which the wolves are moving together after the formation of the pack becomes public knowledge. Those in the pack again have advance knowledge of how they will act and

\footnotetext{
${ }^{100}$ Lu (2016: 778).

${ }^{101}$ Briggs (2007: 698).

102 Becht et al. (2015).
} 
can profit from front-running the market movements they create. The development of the derivatives market made it a lot easier for them to profit from front-running.

If both the anti-cartel spirit of the $5 \%$ rule and the anti-manipulation spirit are so easily compromised, the SEC should tighten up the proxy rule to make it difficult for wolf packs to form and to profit from wolf pact effects. But the SEC has so far neither admitted the failure of the proxy rule change nor done anything to reverse the rule. This inaction only strengthens suspicion that the SEC, supposedly a "self-regulating body", is in effect functioning as a promoter of financial interests captured by shareholder activists who simply clamor for more power and freedom for themselves.

Allowing free communication and engagement with management has similarly failed to bring about "market efficient" outcomes, mainly because shareholders do not all have equal access to management. While corporate executives can ill afford not to be serious in communicating and engaging with big institutional investors, they can simply ignore or offer perfunctory replies to the demands of small shareholders, who lack the larger players' resources. A critical question here is whether big institutional investors and other influential activists engage with management as impartial representatives of the general interests of shareholders or exploit their access to management mainly for their own gain. Common sense, as well as broad anecdotal evidence of institutions' self-serving utilization of communication and engagement with management, favors the latter answer. ${ }^{103}$

Calio and Zahralddin's research pointed out that free communication and engagement with management provides institutional investors with a "tactical edge over the management and small shareholders because it occurs behind-the-scenes without media scrutiny or individual investor awareness." 104 Cioffi similarly concluded: "The 1992 proxy rule changes appear to have

\footnotetext{
${ }^{103}$ For instance, some public pension fund administrators exploited the occasion of engagements for their own career development. "Romano (1993) relates that many public pension fund managers desire elective office and therefore enhance their political reputations by becoming crusaders against the interests of large corporations. Specifically, she tells about a trustee for New York City's pension funds who trumpets her dogged shareholder activism while campaigning to be nominated as a candidate for the United States Senate." Cases of hedge-fund activists ...

${ }^{104}$ Calio and Zahralddin (1994: 522-523). Immediately after the proxy rule amendments, engagement became a more favored method than proxy contest. For instance, "TIAA-CREF reported in 1994 that it had submitted eighteen proposals during the proxy seasons but had "successfully negotiated away fourteen of them" before
} 
encouraged greater governance by institutional investors, but at the expense of transparency. Institutional investors, with some notable exceptions, preferred to voice their concerns and criticisms to management in private communications that would not become public. These communications thus became occasions for managers to disclose significant information to the representatives of institutional investors and analysts associated with investment banks and brokerages."105

In addition, allowing free communication between shareholders and the public, far from evening the aforementioned imbalance between shareholders and management, intensified the imbalance skewed to shareholders. Activist shareholders are now free to criticize the company's management "as long as the statements [they make] are not fraudulent." ${ }^{106}$ In contentious issues, management makes its decisions by weighing their advantages and disadvantages. But activists can just focus on their perceived disadvantages and find whatever faults with management within the boundary of "not being fraudulent. It is even possible to criticize management for not achieving better performance in the name of maximizing shareholder value when the company concerned has been performing well. On the other hand, it is not often easy for management to criticize the company's activist shareholders unless it finds something seriously wrong with their statements or their behavior.

Owing to the free-communication rule, it has now become a convention among hedge-fund activists to criticize management, not only by sending letters but also by publishing "white papers" and even convening press conferences. This kind of public criticism puts enormous pressure on management and, rather than continuing the public warfare, company executives tend to prefer making compromises with activists by yielding to some of their demands, as Steven Solomon's comment in the introduction reveals. ${ }^{107}$

voting" and, without waging a proxy contest, "From November 1992 through December 1993, Ils helped force turnover in top management at American Express, Borden, GM, IBM, Kodak and Westinghouse." (Blair 1995: 171172)

${ }^{105}$ Cioffi (2005: 17, fn. 12).

${ }^{106}$ Calio and Zahralddin (1994: 522-523).

107 Daniel Loeb's (Third Point) attack on Dow Chemical is an example. Loeb opened a website specifically designed to criticize Dow management and their alleged "broken promises". Dow management gave in and accepted two directors nominated by him in return for a one-year truce including the closure of the website. These two directors 


\section{4. "Co-Investments" between hedge-fund activists and institutional investors}

A major reason that hedge-fund activists exert influence over corporations in far excess of their shareholding is that institutional investors often support them implicitly or explicitly. The close ties between hedge-fund activists are multi-faceted. As financial investors, they share a similar world outlook that is focused on shareholder value, which is different from corporate managers whose main responsibility is to create corporate value by producing high-quality, low-cost goods and services. Fund managers in institutional investors are normally evaluated by their short-term performance even if they claim to pursue long-term gains. In this incentive structure, they tend to ally with hedge-fund activists. ${ }^{108}$

The 1996 NSMIA provided a strong impetus to convert the potential "co-investments" between hedge-fund activists and institutional investors into the actual co-investments. As institutional investors are now supplying about $60 \%$ of hedge funds' AUM, they share nearly the same commercial interest when hedge-fund activists campaign against corporations. Of course, institutional investors claim that they vote independently of hedge-fund activists, which is what they are supposed to do. However, it is highly likely that, if an institutional investor holds shares both in a company targeted by an activist hedge fund and in the hedge fund itself, it will know the hedge fund's intended actions in advance and will have an incentive to cooperate with it in order to raise its yield from the hedge-fund investment. Anecdotal evidence of co-investment abounds.

For instance, it was revealed during the proxy battle between Du Pont and Trian Partners that the California Teachers Retirement System (CaLSTRS) -- a leader amongst pension-fund activists and currently the third-largest pension fund in the U.S., with AUM of \$198.7 billion as

\footnotetext{
were under Loeb's "golden leashes" and soon played a central role in pushing Dow Chemical to conclude the merge-and-split deal with DuPont in December 2015.

${ }^{108}$ A Fortune report following the release of a letter to CEOs from BlackRock head Laurence Fink urging a long-term approach offers a vivid illustration: "[T]aking a very small survey of companies in the S\&P 500, [we] immediately ran into two that said the BlackRock analysts covering them had their own short-term demands-for good quarterly results. 'My guy's a fanatic,' reported the CEO of one of those companies. So it cannot be said that Fink's letter has even influenced the whole of BlackRock." (Loomis 2014).
} 
of January 2017 -- had cooperated with Trian's campaign from the beginning. Du Pont's management had never thought of this possibility because CaISTRS was a long-term shareholder and the company "generally had a congenial working relationship with the pension fund". But CaISTRS co-signed an early letter supporting Trian when the latter attacked DuPont in 2015 and turned out later to be one of the hedge fund's major investors. In detailing how Du Pont went to war with Trian, Fortune magazine reported that " $[t]$ ies like that have made it harder for companies like DuPont to argue that siding with activists isn't in the interest of shareholders." 109

The most detailed account of co-investment revealed in public so far has probably been that between CaISTRS and Relational Investors LLC, an activist hedge fund set up by Ralph V. Whitworth and David H. Batchelder, who used to work with T. Boone Pickens as fellow corporate raiders. CaISTRS committed $\$ 1$ billion to Relational, $\$ 300$ million to Trian, and $\$ 100$ million to Starboard in 2013. Working in tandem from the beginning, Relational and CalSTRS increased their participation in Timken, a fifth-generation family business producing highquality steel and bearings, until the holding of each reached the 5\% threshold for a 13D filing. As part of their attempt to push the Timken family into breaking the company into two separate entities and increasing stock buybacks, Relational and CalSTRS set up a website, "unlocktimken.com", that criticized Timken management publicly. An investment officer from CaISTRS joined a roadshow organized by Relational, flying to New York to meet fellow pensionfund managers. A seat on the Timken board was filled by a CaISTRS representative, and "the pension fund, long a champion of better corporate governance, made the case that Timken's board was dominated by family members who paid themselves liberally and put their own interests ahead of shareholders' interests." ${ }^{110}$ In April 2012, three weeks before the proxy vote, Relational and CalSTRS put out a news release calling Tim Timken's $\$ 9$ million pay package in 2011 "grossly out-of-line with other executive chairmen in Timken's peer group." ${ }^{111}$ Their

\footnotetext{
${ }^{109}$ Gandel (2015).

${ }^{110}$ Schwartz (2014)

${ }^{111}$ Relational Investors and CaISTRS press release, “Relational Investors LLC and CaISTRS Urge Timken's Board to Take Action to Separate the Company's Businesses to Unlock Shareholder Value," February 19, 2013, at
} 
proposal to split the company into Timken and TimkenSteel eventually garnered $53 \%$ of shareholder votes. ${ }^{112}$

\section{Conclusions - Rebuilding the engagement and proxy voting system}

The compulsory voting imposed on institutional investors created a large vacuum in the corporate proxy system by forcing those who are uninterested in and incapable of voting to cast their votes by "creating" or "purchasing" justifications for their decisions. This vacuum provided hedge-fund activists, "minority shareholding corporate raiders", with a major playground to exploit for their own profits. The power of hedge-fund activists was enhanced by the proxy rule changes towards "free engagement and communication" that made it easier for them to aggregate scattered votes under the banner of maximizing shareholder value. The 1996 NISMA provided a strong impetus for "co-investments" between hedge-fund activists and institutional investors by allowing the former to attract alternative investments from the latter effectively with no limit.

The combined consequence of those regulatory changes is predatory value extraction in the U.S. economy. Major public corporations routinely disburse nearly all of their profits, and often more, to shareholders in the forms of stock buyback, dividends and deferred taxes while investing less for the future and undertaking "restructuring" simply for the sake of reducing costs. This is tantamount to looting industrial corporations, and is a prime cause of the disappearing middle class as employment has become unstable and insecure. At the heart of these negative consequences lie the distorted reality between financial investors and corporate management and the distorted application of political democracy to shareholder democracy on which those regulatory changes were premised. The changes were ostensibly geared to correcting the "imbalance" of power between public shareholders and "autocratic" corporate management but the power relation was already skewed toward the former in the 1980s and

http://www.businesswire.com/news/home/20130219006721/en/Relational-Investors-LLC-CalSTRS-Urge-

Timken\%E2\%80\%99s-Board.

${ }^{112}$ Schwartz (2014); Orol (2014); Denning (2014). 
this imbalance has continued to be strengthened. The distorted application of political democracy to shareholder democracy provided a justification to impose voting as a fiduciary duty of institutional investors and allowed easy aggregation of public shareholders' votes on the pretext of "free engagement and communication". This further amplified the imbalance of power between public shareholders and corporate management, and made it a mantra for the latter "to settle with hedge funds before it gets to a fight over the control of a company".

If a regulatory change does not bring about the effects it intended, it should be reversed or recalibrated. The three pillars of the SEC mission are (1) to protect investors, (2) to maintain fair, orderly, and efficient markets, and (3) to facilitate capital formation. What is currently happening in the engagement and proxy-voting system does not meet any of these three pillars of the SEC mission. (1) Only strong and active shareholders are protected; (2) Instead of fair, orderly and efficient markets, we have unfair, unruly and manipulated markets; and (3) value extraction, without capital formation, is facilitated. Following are some of my suggestions to rebuild engagement and proxy voting system that will support sustainable value creation and value extraction.

First, the SEC should make it mandatory for shareholders to submit justifications in their proposals on value creation or capital formation of corporations concerned so that they can be discussed openly in making voting decisions. When activist shareholders propose to "disgorge free cash flows" through increasing stock buybacks or dividends, they only argue that, based on their own arbitrary calculation, certain amount of cash flow is "free," that is, it has no effect on running the corporation. They hardly provide justifications for why the "disgorging" is good for value creation and sustainability of the corporation. Indeed, the evocative term "disgorge" betrays a lack of interest in the value-creating capabilities of the companies that have generated this cash flow.

This new regulation will also force corporate executives to think and behave in line with sustainable value creation and value extraction. If it is mandatory for public shareholders to provide justifications for value creation, corporate executives should be prepared to respond to those claims made by public shareholders. The proxy voting system will then turn into an arena to discuss practical ways to promote sustainable value creation and value extraction between 
shareholders and management. This new regulation is also consistent with the general understanding of the purpose of corporations in the legal profession. As Laster and Zeberkiewicz point out, "the existence of the typical corporation is perpetual and the capital provided by common and preferred stockholders is permanent" and "the blockholder director's duties to the corporation require that the director manage for the long term" ${ }^{113}$

Secondly, voting should be removed as a fiduciary duty of institutional investors. The combination of compulsory voting and open voting by uninterested and incapable institutional investors has given illegitimate power to proxy advisory firms such as ISS and opened wide the room for hedge-fund activists to exploit the vacuum in proxy voting for their looting of industrial corporations. If the SEC acknowledges this deviation of the reality from the ideal of institutional activism and the negative consequences of compulsory voting, it is a natural course of action not to impose compulsory voting on institutional investors. Like political voting, it will be fine to let them decide whether to vote or not. Only those institutional investors who are keen to contribute to sustainable value creation and value extraction can then join the proxy voting arena.

Thirdly, as a practical enforcement mechanism to make shareholders to think and behave in terms of sustainable value creation and value extraction, I suggest that the regulatory authorities allow differentiated voting rights that favor long-term shareholders. Value creation or capital formation takes time in overcoming uncertainties through exercising strategic control, organizational integration and financial commitment. It is therefore natural that long-term shareholders are more supportive of value creation than short-term shareholders. However, current financial regulations do not distinguish between long-term and short-term shareholders although many policy-makers and senior SEC officials voice their concerns about "shorttermism". If they are really concerned about it, they should take actions to correct it.

Many European countries are in fact practicing differentiated voting right systems not only for shares controlled by management but also for those held by public shareholders. For instance, France adopted the Florange Act in 2014, whereby shares that are registered for two years automatically receive double voting rights. Similarly, Italy introduced the mechanism of

\footnotetext{
${ }^{113}$ Laster and Zeberkiewicz (2014/2015)
} 
loyalty shares, allowing listed companies to grant up to a maximum of two votes per share to those shareholders who have continuously held their shares for at least two years. Netherlands and Nordic countries have long exercised differentiated voting rights. In Europe, the principal purpose of the differentiated voting right system according to holding period is to encourage longer-term holding and discourage short-termism. ${ }^{114}$

In the United States, dual-class shares are given only to company founders and managers before they list their companies. Differentiated voting rights are not allowed to shareholders who hold the shares after the listing. This clear division in differentiated voting right before and after the listing has contributed to the conventional understanding that dual-class shares are essentially for protecting entrenched founders and the management. This would be also a major reason that the Council of Institutional Investors (CII) has long advocated the abolition of the dual-class share system. ${ }^{115}$ If institutional investors are given multiple voting rights proportionate to their holding period like in Europe, however, many of them are likely to support it. According to a recent McKinsey study, short-term investors hold only $25 \%$ of U.S. stocks while long-term investors hold $75 \%$ of them. ${ }^{116}$ One can envisage the establishment of "holy alliance" between longer-term institutional investors and value-creating executives, replacing the current "unholy alliance" between activist shareholders and value-extracting executives. This new system to encourage long-term shareholding is also consistent with the interests of the ultimate customers of institutional investors such as pensioners and ordinary savers.

Fourthly, the SEC should make it mandatory for both shareholders and management to reveal to the public what they discussed in engagement sessions. "Free engagement" is only free and exclusive to some influential investors and they prefer "private communication that would not become public", making engagement sessions "occasions for managers to disclose significant information". This situation is directly against the spirit of shareholder democracy as

\footnotetext{
${ }^{114}$ Ventoruzzo (2015); Shearman \& Sterling (2017); Stothard (2015); Shin (2015); ISS (2017)

${ }^{115}$ It states as follows: "ClI's corporate governance policies endorse the principle of "one share, one vote": each share of a public company's common stock should have one vote." (Cll website,

http://www.cii.org/dualclass_stock, accessed on March 20, 2017)

${ }^{116}$ Darr and Koller (2017)
} 
well as the SEC's mission "to protect investors" and "to maintain fair, orderly and efficient markets". Fund managers whose compensation packages are mostly dependent on their trading performance have every incentive to exploit undisclosed information for trading. But corporate managers, even if they recognize those fund managers are utilizing insider information acquired from engagement sessions, cannot report it to regulatory authorities because they will be penalized by the fact that they had revealed it to the fund managers. Prohibiting "fraud and deceit", including profiting from insider information, has always been a critical part of the SEC's mission. There is no reason why engagement should be an exception to the mission.

Fifthly, hedge funds should be put under regulations equivalent to institutional investors. Hedge funds are already big enough to pose systemic risks to the economy, as we witnessed from the collapse of Long-Term Capital Management (LTCM) in 1998. Since the passing of the 1996 NSMIA, hedge funds manage a large portion of institutional investors' funds for the benefit of their ultimate customers, including ordinary workers and pensioners. There is no plausible reason why hedge funds should be still treated as "private entities" and freed from financial regulations applied to institutional investors since they are basically functioning as institutional investors.

As David Dayen points out, "[t]heir emergence was an accident of history, a gift to wealthy families. But the by-product of that gift has now grown to outsized proportions and shoved itself into practically every aspect of economic life." ${ }^{\prime 117}$ In particular, activist hedge funds serve a small group of affluent people at the expense of ordinary people through its deleterious effects on value creation and its power to engage in predatory value extraction. The SEC should put hedge funds under the Investment Act of 1940, and mandate disclosure of their shareholdings and regulate their use of leverage accordingly.

Sixth, the SEC should raise barriers against "wolf packs" and "co-investment." The 1992 proxy rule amendments allowed investor cartels, resulting in frequent emergence of "wolf packs" and "co-investments." The policy of encouraging investor cartels cannot be justified by the SEC's mission, let alone from the perspective of value creation. It should then be repealed. I

${ }^{117}$ Dayden (2016). 
propose lowering the $5 \%$ threshold significantly, say, up to $2 \%$. The ten-day window that Section 13d(1) gives to "insurgents" should be also reduced significantly, say, to two business days. I also propose that the SEC makes it mandatory for hedge funds to reveal their institutional investors who also hold shares of the companies against whom they campaign. 


\section{Bibliography}

Bainbridge, Stephen M. (2005), 'Shareholder Activism and Institutional Investors', UCLA School of Law, Law-Econ Research Paper No. 05-20, at https://papers.ssrn.com/sol3/papers.cfm?abstract_id=796227.

Becht, Marco, Julian Franks, Jeremy Grant and Hammes F. Wagner (2015), The Returns to Hedge Fund Activism: An International Study, ECGI Working Paper Series in Finance, at http://ssrn.com/abstract=2376271.

Bethel, Jennifer E. and Stuart L. Gillan (2002), 'The Impact of the Institutional and Regulatory Environment on Shareholder Voting', Financial Management, 31(4): 29-54.

Bew, Robyn and Richard Fields (2012), 'Voting Decisions at US Mutual Funds: How Investors Really Use Proxy Advisers', at https://ssrn.com/abstract=2084231.

Birch, S. (2009), Full Participation: A Comparative Study of Compulsory Voting, Manchester University Press.

Blair, Margarete (1995), Ownership and Control: Rethinking Corporate Governance for the Twenty-First Century, The Brookings Institution.

Bogle, John (2005), The Battle for the Soul of Capitalism, Yale University Press.

Board of Governors of the Federal Reserve System (2017), “Federal Reserve Statistical Release Z.1 Financial Accounts of the United States: Flow of Funds, Balance Sheets, and Integrated Macroeconomic Accounts", Table F-223: Corporate Equities, at https://www.federalreserve.gov/releases/z1/current/.

Brennan, J. and Hill, L. (2014), Compulsory Voting: For and Against, Cambridge University Press.

Briggs, Thomas W. (2007), 'Corporate governance and the new hedge fund activism: an empirical analysis', Journal of Corporation Law, 32(4): 682-738.

Burger, Dani (2017), 'The U.S. Stock Market Belongs to Bots', Bloomberg, 16 June 2017 (https://www.bloomberg.com/news/articles/2017-06-15/it-s-a-quant-s-stock-market-ascomputer-programs-keep-on-buying).

Calio, Joseph Evan and Rafael Xavier Zahralddin (1994), 'The Securities and Exchange Commission's 1992 Proxy Amendments: Questions of Accountability', Pace Law Review 14(2): 460-539.

Chandler, Beverly (2016), 'Event driven paper finds investors disenchanted', AlphaQ, at http://www.alphaq.world/2016/06/20/240734/event-driven-paper-finds-investors-disenchanted.

Cheffins, Brian R. (2013), The History of Corporate Governance, in Mike Wright, Donald S. Siegel, Kevin Keasey, and Igor Filatotchev (2013), ed., The Oxford Handbook of Corporate Governance, Oxford University Press. 
Cheffins, Brian R. and John Armour (2011), 'The Past, Present, and Future of Shareholder Activism by Hedge Funds, The Journal of Corporation Law, Vol. 37.

Clark, John Bates (1900), Atlantic Monthly, January.

Coffee, John C. and Palia, Darius (2015), 'The Wolf at the Door: The Impact of Hedge Fund Activism on Corporate Governance', Columbia Law and Economics Working Paper

Cioffi, John W. (2005), 'Corporate Governance Reform, Regulatory Politics, and the Foundations of Finance Capitalism in the United States and Germany', CLPE Research Paper No. 6, at https://ssrn.com/abstract=830065.

Craig, Sussane (2013), 'The Giant of Shareholders, Quietly Stirring', The New York Times, at http://www.nytimes.com/2013/05/19/business/blackrock-a-shareholding-giant-is-quietly-stirring.html.

Danneman, Justin (2017), 'A.I. Controls the Stock Market', Squawker, 7 August 2017

(https://squawker.org/analysis/robots-control-the-stock-markets/).

Darr, Rebecca and Tim Koller (2017), 'How to build an alliance against corporate short-termism', McKinsey \& Company, at http://www.mckinsey.com/business-functions/strategy-and-corporatefinance/our-insights/how-to-build-an-alliance-against-corporate-short-termism.

Dayen, David (2016), 'What Good are Hedge Funds?', The American Prospect, at http://prospect.org/article/what-good-are-hedge-funds.

Denning, Steve (2014), 'When Pension Funds Become Vampires', Forbes, at http://www.forbes.com/sites/stevedenning/2014/12/10/when-pension-funds-becomevampires/\#704aac67510c.

Drucker, Peter (1976), The Unseen Revolution: How Pension Fund Socialism Came to America, Harper \& Row.

Fichtner, Jan and Heemskerk, Eelke M. and Garcia-Bernardo, Javier (2017), 'Hidden Power of the Big Three? Passive Index Funds, Re-Concentration of Corporate Ownership, and New Financial Risk, Business and Politics, April 2017. Available at SSRN: https://ssrn.com/abstract=2798653 or http://dx.doi.org/10.2139/ssrn.2798653

Foley, Steven (2016), 'The so-called death of event-driven investing', Financial Times, at https://www.ft.com/content/cc45d8ee-e135-11e5-9217-6ae3733a2cd1.

Foley, Steven and Miles Johnson (2014), 'Event-driven' hedge funds leap into lead after rush to invest', Financial Times, at https://www.ft.com/content/d9a8b122-d61b-11e3-a239-00144feabdc0.

Gandel, Stephen (2015), 'How DuPont went to war with activist investor Nelson Peltz', Fortune, at http://fortune.com/2015/05/11/how-dupont-went-to-war/.

Gelter, Martin (2013), 'The Pension System and the Rise of Shareholder Primacy'. Seton Hall Law Review, 
43(3): 909-970.

Gillan, Stuart and Laura T. Starks (2007), 'The Evolution of Shareholder Activism in the United States', at http://ssrn.com/abstract=959670.

Iliev, Peter and Michelle Lowry (2015), 'Are mutual funds active voters?', Review of Financial Studies, 28(2): 446-485.

ISS (2016), 'About ISS', at https://www.issgovernance.com/about/about-iss/.

ISS (2017), 'Analysis: Differentiated Voting Rights in Europe', at

https://www.issgovernance.com/analysis-differentiated-voting-rights-in-europe/.

Karpoff, Jonathan M. (2001), 'The Impact of Shareholder Activism on Target Companies: A Survey of Empirical Findings', at

https://www.researchgate.net/profile/Jonathan_Karpoff/publication/243782548_The_Impact_of_Share holder_Activism_on_Target_Companies_A_Survey_of_Empirical_Findings/links/55df3f4608aede0b572b 8a91.pdf.

Laide, John (2014), 'Activists Increasing Success Gaining Board Seats at U.S. Companies', at https://www.sharkrepellent. net/request?an=dt.getPage\&st= undefined\&pg=/pub/rs_20140310. htmI\&rnd=176396.

Laster, Travis J. and John Mark Zeberkiewicz, (2014), 'The Rights and Duties of Blockholder Directors', The Business Lawyer, 70(1): 33-60.

Lazonick, William (2007), 'The U.S. Stock Market and the Governance of Innovative Enterprise', Industrial and Corporate Change, 16(6): 1021-1022.

Lazonick, William (2014), 'Innovative Enterprise and Shareholder Value', Law and Financial Markets Review, 8(1): 52-64.

Lazonick, William (2015a), 'The Theory of Innovative Enterprise: Foundation of Economic Analysis', Academic-Industry Research Working Paper \#13-0201.

Lazonick, William (2015b), 'Labor in the Twenty-First Century: The Top 0.1\% and the Disappearing Middle-Class', in Weller, Christian E. (2015) (ed.), Inequality, Uncertainty, and Opportunity: The Varied and Growing Role of Finance in Labor Relations, Cornell University Press.

Lazonick, William (2016), 'The Value-Extracting CEO: How Executive Stock-Based Pay Undermines Investment in Productive Capabilities', Institute for New Economic Thinking, Working Paper No. 54.

Lazonick, William and Mary O'Sullivan (1997), 'Finance and Industrial Development, Part I: The United States and the United Kingdom', Financial History Review, 4(1): 7-29.

Lazonick, William and Mary O'Sullivan (2000), 'American Corporate Finance', in Singh, Ajit (ed.) (2000), Competitiveness Matters, Michigan University Press. 
Lazonick, William, Matt Hopkins and Ken Jacobson (2016), 'What we learn about inequality from Carl Icahn's \$2 billion Apple 'no brainer", at https://www.ineteconomics.org/perspectives/blog/what-welearn-about-inequality-from-carl-icahns-2-billion-apple-no-brainer.

Lazonick, William and Jang-Sup Shin (2018), Value Creation and Value Extraction: The Manifesto to Reclaim Sustainable Prosperity (book manuscript).

Loomis, Carol (2014), 'BlackRock: The \$4.3 trillion force', Fortune, at http://fortune.com/2014/07/07/blackrock-larry-fink/.

Lu, Carmen X.W., (2016), 'Unpacking Wolf Packs', Yale Law Journal, 125(3), at http://www.yalelawjournal.org/comment/unpacking-wolf-packs.

Malanga, Steven (2013), 'The Pension Fund That Ate California', City Journal, at https://www.cityjournal.org/html/pension-fund-ate-california-13528.html.

Marriage, Madison (2013), 'Activist investors fuel event-driven returns', Financial Times, at https://www.ft.com/content/faafbd08-ea1b-11e2-b2f4-00144feabdc0.

Monks, Robert (2013), 'Robert Monks: It's broke, let's fix it', Listed Magazine, at http://listedmag.com/2013/06/robert-monks-its-broke-lets-fix-it/.

Monks, Robert (2015), 'Careless language or cunning propaganda', RFK Compass event, at http://www.ragm.com/libraryFiles/145.pdf.

Orol, Ronald (2014), 'Teaming up with CalSTRS helps activist funds get their way', Harvard Roundtable on Shareholder Engagement - Consolidated Background Materials, at http://www.law.harvard.edu/programs/corp_gov/shareholder-engagement-roundtable-2015materials/Harvard-Roundtable-on-Shareholder-Engagement-Consolidated-Background-Materials.pdf.

Ott, Julia (2011), When Wall Street Met Main Street: The Quest for Investors' Democracy, Harvard University Press.

Perino, Michael (2010). The Hellhound of Wall Street: How Ferdinand Pecora's Investigation of the Great Crash Forever Changed American Finance, Penguin Press.

Preqin (2016), '2016 Preqin Global Hedge Fund Report - Sample pages', at https://www.preqin.com/docs/samples/2016-Preqin-Global-Hedge-Fund-Report-Sample-Pages.pdf.

Roe, Mark (1990), 'Political and legal restraints on ownership and control of public companies', Journal of Financial Economics 27 (July): 7-41.

Roe, Mark (1991), 'Political Elements in the Creation of Mutual Fund Industry', University of Pennsylvania Law Review, 139(6): 1469-1511. 
Romano, Roberta (1993), 'Public Pension Fund Activism in Corporate Governance Reconsidered', Columbia Law Review, 93(4): 793-853.

Rose, P. (2007), 'The Corporate Governance Industry', The Journal of Corporation Law, 32(4): 887-926.

Rosenberg, Hilary (1999), A Traitor to His Class, John Wiley \& Sons.

Salmon, Felix and Jon Stokes (2010), 'Algorithms Take Control of Wall Street', Wired 27 December 2010 (https://www.wired.com/2010/12/ff_ai_flashtrading/?mbid=email_onsiteshare).

Schmalz, Martin C. (2017), 'Common Ownership and Competition: Facts, Misconceptions, and What to Do about It', Hearing on Common Ownership by institutional investors and its impact on competition, OECD Directorate for Financial and Enterprise Affairs Competition Committee. Available at https://one.oecd.org/document/DAF/COMP/WD\%282017\%2993/en/pdf.

Schmalz, Martin C. (2018), 'Common-Ownership Concentration and Corporate Conduct', Annual Review of Financial Economics, Vol. 10, December 2018; CESifo Working Paper Series No. 6908. Available at SSRN: https://ssrn.com/abstract=3046829

Schwartz, Nelson D. (2014), 'How Wall Street Bent Steel: Timken Bows to Activist Investors, and Splits in Two', The New York Times, at https://www.nytimes.com/2014/12/07/business/timken-bows-toinvestors-and-splits-in-two.html?_r=0.

Securities and Exchange Commission (1992), Final Proxy Rule Amendments, Exchange Act Release No. 31,326, [1992 Transfer Binder] Fed. Sec. L. Rep. (CCH) 1185,051, at 83,353.

Securities and Exchange Commission (2000), 'Final Rule: Selective Disclosure and Insider Trading', at https://www.sec.gov/rules/final/33-7881.htm.

Securities and Exchange Commission (2003), Final Rule: Proxy Voting by Investment Advisers, 17 CFR Part 275, Release No. IA2106; File No. S73802, RIN 3235AI65, at https://www.sec.gov/rules/final/ia2106.htm.

Securities and Exchange Commission (2017), 'Private Funds Statistics - Second Calendar Quarter 2016', January 17, 2017, at https://www.sec.gov/divisions/investment/private-funds-statistics/private-fundsstatistics-2016-q2-accessible.pdf.

Sharara, Norma M and Hoke-Witherspoon, Anne E. (1993), 'The Evolution of the 1992 Shareholder Communication Proxy Rules and Their Impact on Corporate Governance', The Business Lawyer, 49(1): 327-358.

Shearman \& Sterling (2017), 'The Proportionality Principle in the European Union', Report commissioned by the European Commission, at http://ec.europa.eu/internal_market/company/docs/shareholders/study/final_report_en.pdf. 
Shin, Jang-Sup (2015), 'The Reality of "Actions" by Activist Hedge Funds and Public Policies on Chaebols', The KERI Insight, at http://fiid.org/wp-content/uploads/2015/07/Activist-fund-and-chaebol-policy-KERIInsight-2015-7-1.pdf.

Singh, S. P. (2015), 'Compulsory Voting and the Turnout Decision Calculus', Political Studies, 63(3): 548568.

Smith, Michael P. (1996), 'Shareholder Activism by Institutional Investors: Evidence from CalPERS', The Journal of Finance, 51(1): 227-252.

Solomon, Steven Davidoff (2015), 'Remaking Dow and DuPont for the Activist Shareholders', The New York Times, December 15, at https://www.nytimes.com/2015/12/16/business/dealbook/remaking-dowand-dupont-for-the-activist-shareholders.html? $r=0$.

Stothard, Michael (2015), 'French companies fight back against Florange double-vote law', The Financial Times, at https://www.ft.com/content/05314dfe-e27d-11e4-ba33-00144feab7de.

Strickland, Deon, Kenneth Wiles and Marc Zenner (1996), 'A requiem for the USA - Is small shareholder monitoring effective?', Journal of Financial Economics 40(2): 319-338.

Strine, Jr Leo E. (2005), 'The Delaware Way: How We Do Corporate Law and Some of the New Challenges We (and Europe) Face', Delaware Journal of Corporate Law, 30(3): 673-696.

Strine, Jr Leo E. (2007), 'Toward common sense and common ground? - Reflections on the shared interests of managers and labor in a more rational system of corporate governance', Harvard Law and Economics, Discussion Paper No. 585.

U.S. Senate Committee on Banking and Currency (2009), The Pecora Report: The 1934 Report on the Practices of Stock Exchanges from the Pecora Commission.

Ventoruzzo, Marco (2015), 'The Disappearing Taboo of Multiple Voting Shares: Regulatory Responses to the Migration of Chrysler-Fiat', Bocconi Legal Studies Research Paper No. 2574236, available at https://ssrn.com/abstract=2574236.

Winter, Jaap W. (2011), 'Shareholder Engagement and Stewardship: The Realities and Illusions of Institutional Share Ownership' at https://ssrn.com/abstract=1867564.

Wong, Simon (2010), 'Why Stewardship is Proving Elusive for Institutional Investors', Butterworths Journal of International Banking and Financial Law, at http://ssrn.com/abstract=1635662. 